
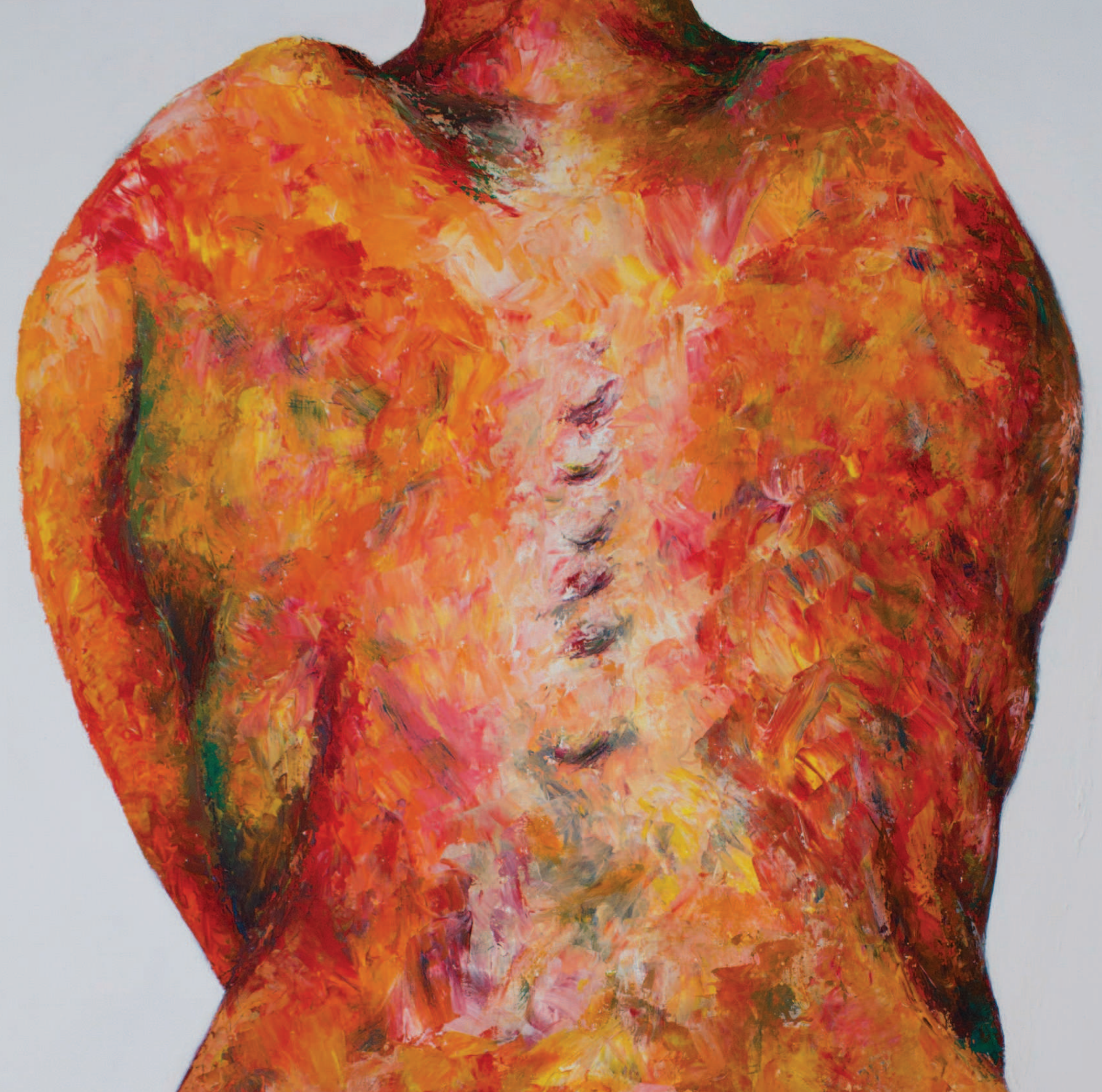

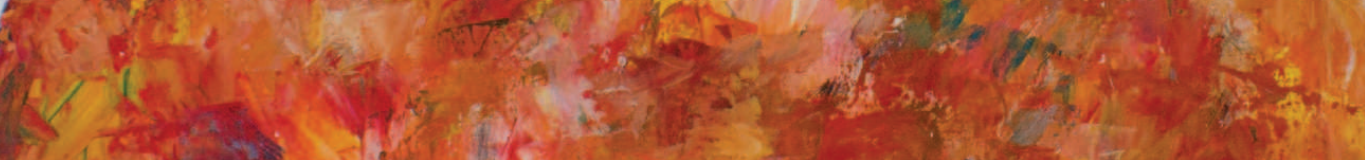

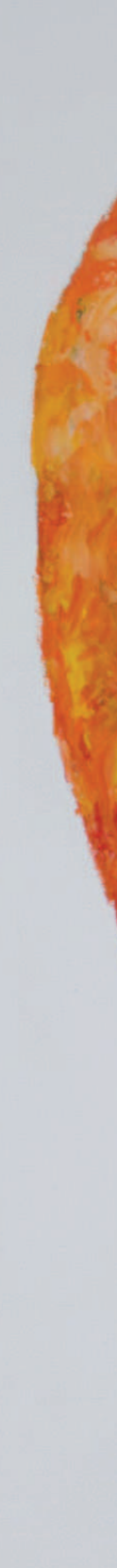

1

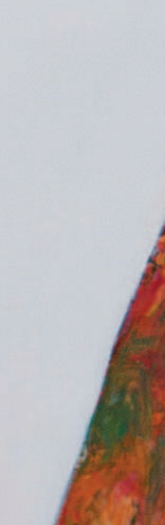

2.

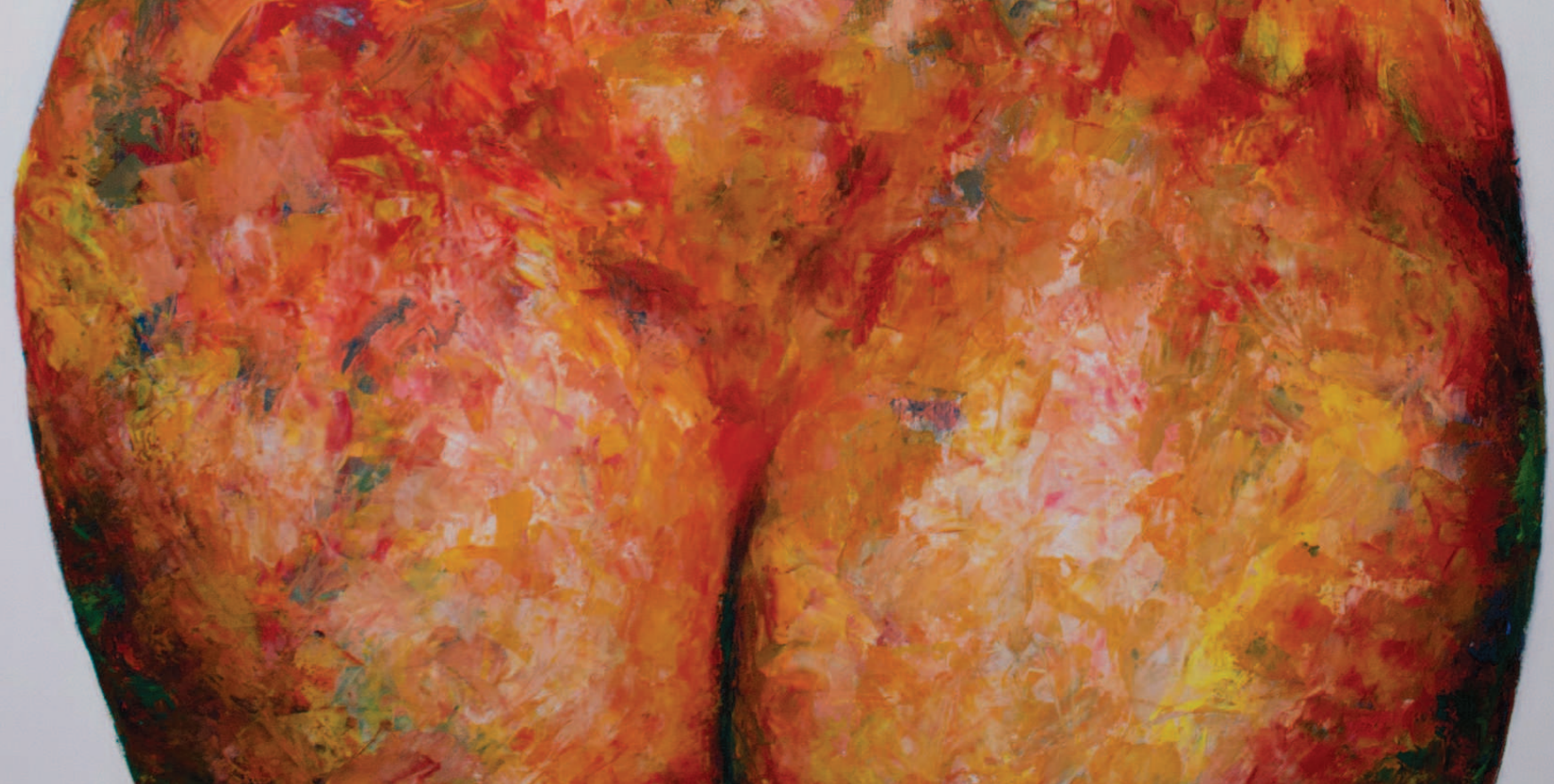




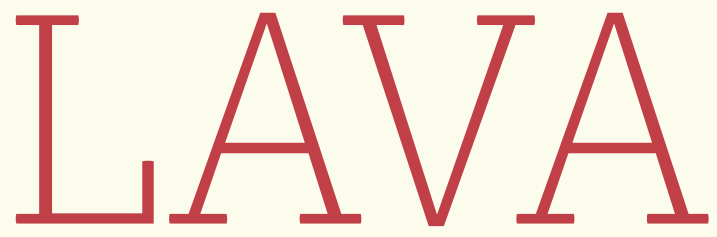

Matéria liquida lançada pelos vulcões.

Torrente, enxurrada, curso. 


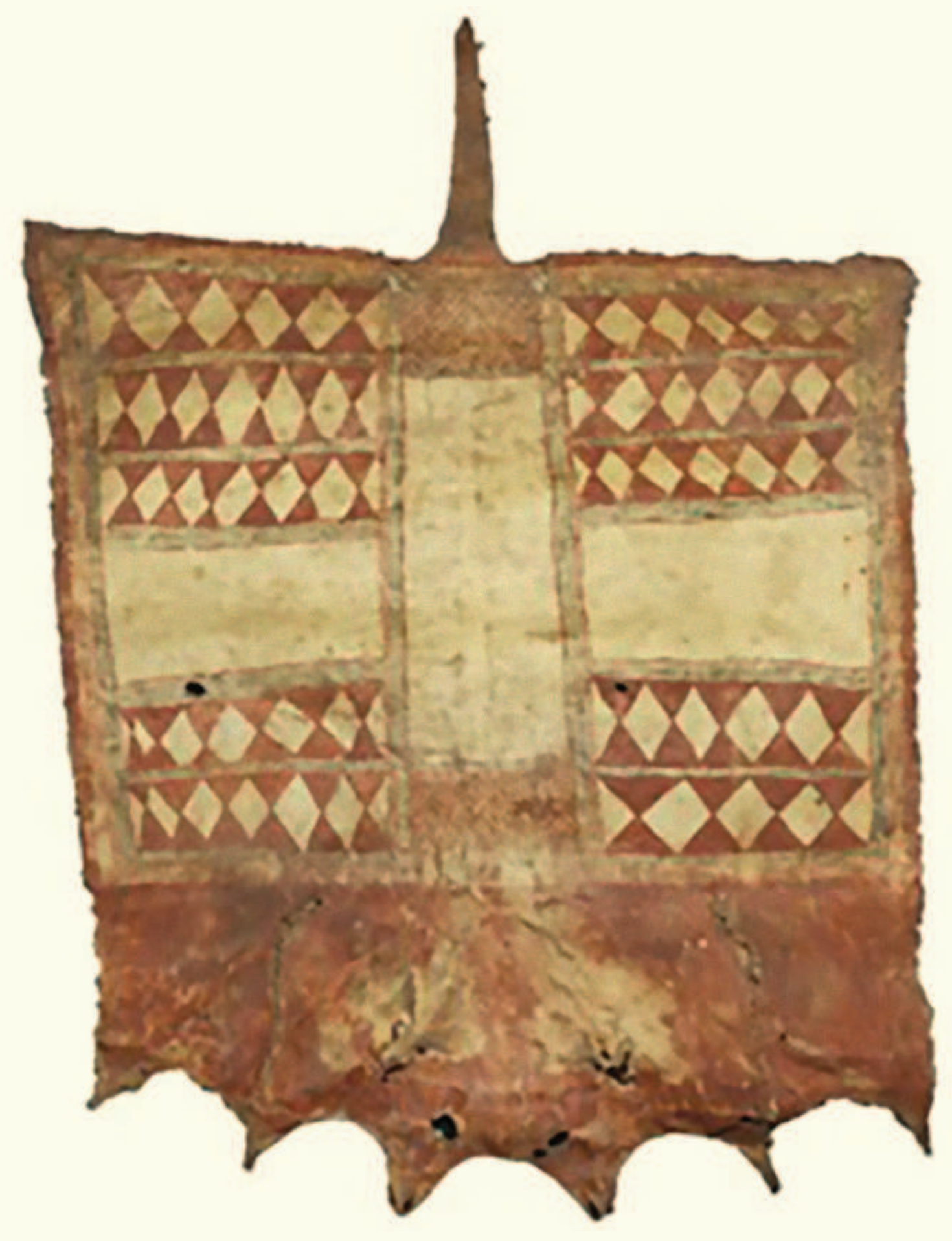

\section{LITERATURAS DA FLORESTA}

Textos de conclusão do curso ministrado no segundo semestre de 2014 e indicados para publicação pela Profa Lúcia Sá. 


\title{
JAGUANHENHÉM: UM ESTUDO SOBRE A LINGUAGEM DO IAUARETÊ
}

\author{
- MARCEL TWARDOWSKY ÁVILA \\ - RODRIGO GODINHO TREVISAN
}

\section{RESUMO}

Em Meu tio o Iauaretê, Guimarães Rosa empreende em prosa um grande experimentalismo com relação à linguagem, utilizando-a como um instrumento em que, por meio da mescla entre o português e o tupi, aflora o hibridismo do narrador homem-onça. $\mathrm{O}$ uso do tupi no conto, sobretudo na forma do nheengatu, é bastante denso, devido a isso um estudo da elaborada linguagem da obra mostra-se muito revelador. Abordamos ao longo deste ensaio as variadas formas pelas quais o tupi mescla-se à língua portuguesa na narrativa de Rosa e sugerimos interpretações que decorrem do estudo desse hibridismo linguístico, que confere singularidade à linguagem denominada jaguanhenhém. Por fim, fornecemos um glossário em que listamos e traduzimos os termos tupis utilizados por Rosa. Desse modo, este trabalho busca preencher uma lacuna apontada por Haroldo de Campos em seu conhecido ensaio A Linguagem do Iauaretê.

Palavras-chave: Guimarães Rosa; português; tupi; hibridismo; homem-onça.

\section{ABSTRACT}

In Meu tio o Iauaretê, Guimarães Rosa renders a great experimentalism regarding language into prose, using it as an instrument in which the jaguar-man narrator's hybridism emerges, by means of a blend of Portuguese and the Tupi language. The use of the Tupi language, especially in the Nheengatu form, is remarkably dense, because of that a study of the elaborate language in this work turns out to be quite revealing. Throughout this paper, we approach the various forms in which the Tupi language blends with Portuguese in Rosa's narrative, and suggest interpretations that stem from the study of such linguistic hybridism, which endows some uniqueness to the language denominated Jaguanhenhém. Finally, we present a glossary in which we listed and translated the items in the Tupi language used by Rosa. Thereby, this paper aims at filling a gap pointed out by Haroldo de Campos in his well-known A Linguagem do Iauaretê essay.

Keywords: Guimarães Rosa; portuguese; tupi language; hybridism; jaguar-man.

\section{MUATUKASAWA}

Meu tio o Iauaretê upé Guimarães Rosa umunhã manungara amurupi retana marandua nheenga irúmu. Aé umupuraki kuá nheenga, umunáni uaá tupi português irúmu, maié iepé tendaua mamé usini nhaã mira-iauareté 
munanisaua. Aikué siía maã tupi suiuara kuá marandua nheenga resé, aintá uiukuau píri nheengatu rupi. Iasikári ramé iakuau puranga píri kuá marandua nheenga reseuara aé umukameẽ siía maã iandé arama. Kuá muraki upé iamukameẽ maiesaua-itá marupi tupi uiumunáni português irúmu kuá Rosa mbeusaua upé, asuí ianheé maã usêmu-kuau iandé arama kuá jaguanhenhém suí iasikári ramé i rupi. Pauasá-pe iameẽ iepé nheenga-tiua mamé iambúri panhẽ nheenga-itá tupi suiuara Rosa umupinima uaá kuá marandua resé, asuí iamusasá aintá português kiti. Kuá iané muraki úri, aramé, upurakári iepé tendaua ipuraíma uaá kuera, maié umukameẽ uana Haroldo de Campos i muraki serakuena upé, sera uaá A Linguagem do Iauaretê.

Nheenga-itá tuixaua: Guimarães Rosa; português; tupi; munanisawa; mira-iauareté.

\section{INTRODUÇÃO}

$\mathrm{H}$ aroldo de Campos (HC), em seu conhecido ensaio A Linguagem do Iauaretê, afirma que o conto Meu tio o Iauaretê, de Guimarães Rosa (GR), representa, a seu ver, o estágio mais avançado do experimento desse autor com a prosa. Tal afirmação é estabelecida conforme a justificativa de que nessa obra "não é a história que cede o primeiro plano à palavra, mas a palavra que, ao irromper em primeiro plano, configura a personagem e a ação, devolvendo a história" (CAmpos, 1992, p. 59).

A inovação linguística em Meu tio o Iauaretê concretiza-se por meio da mescla de vocábulos tupis e portugueses, ora estes exercendo influências sobre aqueles, ora aqueles sobre estes. A densa presença do léxico tupi mesclado à língua portuguesa ao longo do conto é o principal elemento de hibridismo da obra, que simbolicamente abarca e representa todas as outras dualidades atribuídas ao narrador. Em várias passagens os vocábulos indígenas intercalam-se com termos lusitanos semanticamente equivalentes, conferindo ao texto uma natureza bilíngue de autotradução. Isso permite uma intensa utilização dos vocábulos tupis sem que haja uma perda danosa de entendimento por parte dos leitores.

Há de se considerar que a língua tupi majoritariamente empregada no conto não é a língua falada à época da chegada dos primeiros europeus à terra posteriormente chamada Brasil, mas sim o nheengatu, como também passou a ser chamada a evolução da língua geral amazônica a partir de meados do século 19. Antes de nos atermos à análise do conto e à sua linguagem, passemos a um breve histórico do idioma tupi e das línguas gerais que dele se originaram. 


\subsection{O tupi e as línguas gerais}

Ao chegarem ao litoral das terras que constituem atualmente $o$ Brasil, os colonizadores europeus se depararam com povos que falavam em sua maioria o idioma que seria, posteriormente, chamado de tupi, inicialmente também denominado língua brasílica. Este foi o idioma vigente em algumas das primeiras povoações e aldeamentos coloniais em solo brasileiro, dando origem a, pelo menos, duas línguas gerais ${ }^{1}$ cujos usos se expandiram por vastos territórios: a língua geral paulista e a língua geral amazônica.

A língua geral paulista, também conhecida por língua geral meridional ou tupi austral, formou-se no ambiente mestiço da capitania de São Paulo do século 16, a partir do tupi de São Vicente e do vale do Tietê. Esse idioma teve seu uso difundido no contexto das bandeiras e entradas para territórios até então alheios ao uso do tupi, como terras que hoje pertencem a Minas Gerais, Goiás, Mato Grosso e norte do Paraná. Segundo Sérgio Buarque de Holanda (1995, p. 129), essa língua provavelmente perdeu o predomínio em tais territórios já na primeira metade do século 18, sendo gradativamente sobrepujada pelo idioma lusitano. Os últimos registros, de que temos conhecimento, de contatos com falantes da língua remontam às primeiras décadas do século 19, como os relatos de Auguste de Saint-Hilaire (1937, pp. 253, 254 e 255) e de Hercule Florence (apud: HolANDA, 1995, p. 130). Atualmente a língua geral paulista não mais possui falantes e carece de estudos mais aprofundados, tanto no âmbito linguístico como no que concerne à sua história social, o que é dificultado pelos escassos registros escritos que se têm a seu respeito.

O processo de formação da língua geral amazônica (LGA) remonta ao início do processo colonial nas terras do Grão-Pará em 1616, ano em que as primeiras tropas portuguesas se estabeleceram na região da Costa do Salgado, fundando o Forte do Presépio. Ao chegarem à região litorânea dos atuais estados do Maranhão e Pará, os colonizadores se depararam com índios tupinambás, falantes de uma variante dialetal da mesma língua tupi com a qual já haviam entrado em contato na costa atlântica de Pernambuco. Esta se tornou a principal língua veiculada nos

[1] Há indícios de que teria se formado também uma língua geral de base tupi no sul da Bahia. Para mais informações sobre esse assunto, cf. Loвo, Tânia C. Freire et al. "Indícios de língua geral no sul da Bahia na segunda metade do século XVIII”. In: LoBo, Tânia et al. (Org.). Para a história do português brasileiro. vi: novos dados, novas análises. Salvador: EdufBa, pp. 609-630. 
aldeamentos missionários que se formaram nessa região para a catequização dos indígenas. À medida que tais aldeamentos passaram a subir os rios amazônicos, congregando indígenas das mais variadas proveniências étnicas e linguísticas, o tupi perdia o caráter de idioma étnico dos tupinambás e transformava-se num vernáculo supraétnico, servindo à comunicação entre europeus e autóctones de variadas etnias. Ao longo desse processo, o idioma teve sua tipologia gradativamente afastada da do idioma dos tupinambás, devido, justamente, às influências resultantes de constantes contatos com outros sistemas linguísticos. A partir da segunda metade do século 19, após um contínuo processo de variadas alterações, esse idioma passa a ser nomeado também como nheengatu². Nesse momento, por vários motivos ${ }^{3}$, a língua portuguesa já ganhava espaço na região amazônica e a língua geral, por sua vez, passava a ter cada vez menos falantes.

Hoje em dia, apesar da expressiva diminuição do número de seus falantes, o nheengatu continua servindo à comunicação de alguns milhares de habitantes da Amazônia, sobretudo na região do Alto Rio Negro, em territórios do Brasil, da Venezuela e da Colômbia, onde a Lei 145/2002, aprovada no dia 22 de novembro de 2002, concedeu a esse idioma, junto ao tukano e ao baniwa, a condição de língua cooficial do município de São Gabriel da Cachoeira, no estado do Amazonas.

Foi, contudo, justamente na segunda metade do século 19 e começo do século 20, após o início do referido processo de declínio no número de seus falantes, que um crescente interesse pelo idioma levou à composição de diversas obras sobre o nheengatu, como o dicionário do conde italiano Ermano Stradelli, publicado em 1929, e a gramática do amazonense Pedro Luis Símpson, cuja primeira edição é de 1877. Além disso, nessa época, viajantes coletaram e traduziram a literatura oral que era transmitida em nheengatu, publicando-a em obras bilíngues - nheengatu/português. São os casos do general Couto de Magalhães, cuja obra, O Selvagem, foi publicada em 1876; do botânico João Barbosa Rodrigues, autor de Poranduba Amazonense, obra publicada em 1890; e de Antônio Brandão de Amorim, cujas Lendas em Nheengatu e em Português foram publicadas postumamente na revista do Instituto Histórico e Geográfico Brasileiro

[2] Este nome significa "língua boa" (nheenga "língua" + katu "boa"), em referência à amplitude das comunicações que ela possibilitava, entre diversas etnias e numa vasta área geográfica.

[3] Para informações detalhadas a respeito dos processos de expansão e declínio da LGA, cf. FreIRE, José Ribamar Bessa. Rio Babel: a história das línguas na Amazônia. 2. ed. Rio de Janeiro: EdUERJ, 2011. 
(IHGB), em 1926. Amorim, na realidade, traduziu e organizou narrativas coletadas por um indígena chamado Maximiano José Roberto, que não levou créditos na publicação (FREIRE, 2011, p. 145). Essas obras marcam um período em que as traduções do nheengatu para o português foram importantes, tendo desdobramentos na história da literatura brasileira, já que serviram de inspiração ao movimento modernista, não só pela linguagem, mas também pelas tramas pioneiras. Segundo o historiador Bessa Freire, "Mário de Andrade, com Macunaíma, e Raul Bopp, com Cobra Norato, talvez tenham sido os escritores que mais dívidas contraíram" com os autores desses textos (FREIRE, 2011, p. 146). GR também teve contato com obras sobre o nheengatu e bebeu muito dessas fontes para a construção de seu jaguanhenhém. Assim sendo, apesar da obviedade de tal observação, é bom atentarmos para a natureza extremamente autoral da linguagem do sobrinho do iauaretê, pela ficcionalidade de um falante de nheengatu encontrar-se em pleno sertão mineiro.

No entanto, um elo entre ficcionalidade e realidade pode ser estabelecido se atentarmos ao nome do grupo indígena a que a mãe do homem-onça pertencia: “(...) minha mãe, gentio Tacunapéua, muito longe daqui” (RosA, 2007, p. 215). Os etnônimos tacunapeua e peua referem-se ao povo também conhecido como taconhapé, grupo que, segundo o padre João Felipe Bettendorf, utlizava a língua geral e habitava a região do sertão do Xingu, "o religioso refere-se inclusive a esse espaço como 'sertão dos Taconhapé", (Bettendorf apud Chambouleyron \& Melo, 2008, p. 1). O povo taconhapé, segundo Curt Nimuendaju, desapareceu no final do século XIX e começo do século XX (Nimuendaju apud Chambouleyron, 2008, p. 55).

É curioso notar que implicitamente GR parece justificar a ocorrência da língua geral no sertão mineiro ao mencionar o nome do grupo tacunapeua. Com isso, são reforçados os laços linguísticos que o narrador mestiço possui com sua falecida mãe, manifestos em sua fala, repleta de nheengatu.

Apesar das considerações feitas anteriormente, com o objetivo de distinguirmos o tupi antigo, registrado pelos jesuítas nos séculos 16 e 17, da LGA, em seus distintos estágios históricos, é preciso dizer que em nossa análise não seremos sempre tão precisos quanto à nomeação linguística, valendo-nos, por vezes, do termo "tupi" de forma genérica, com relação a todos os dialetos e estágios de evolução da língua brasílica dos primeiros séculos coloniais e com relação às línguas gerais de base tupi. Assim, pretendemos evitar ao longo do texto um adensamento tecnicista que prejudique a compreensão daquilo que nos parece mais essencial. $\mathrm{O}$ termo "tupi”, além do mais, é passível dessa utilização abrangente, pois foi ao longo dos séculos utilizado de forma genérica para as mencionadas variantes regionais e diacrônicas, o que é corroborado pelo fato do 
nheengatu ser conhecido, ainda hoje, como "tupi amazônico" ou "tupi moderno". Vale dizer ainda que durante muito tempo não foi clara, entre estudiosos do assunto, escritores e poetas, a distinção entre o tupi antigo e o nheengatu, sendo este muitas vezes tomado por aquele. Basta, portanto, termos em mente que a influência tupi mais direta na linguagem do conto provém do nheengatu. Na medida em que essa língua, por sua vez, tem o tupi antigo como base, quase toda a sua influência remonta ao tupi antigo. Distinções mais precisas serão feitas quando as considerarmos necessárias ou enriquecedoras para o escopo do trabalho 4 .

Além da breve análise de alguns aspectos da linguagem que GR utiliza no conto, cujo objetivo é o de mostrar a variedade de formas que o hibridismo assume no texto, elaboramos também um glossário ${ }^{5} \mathrm{com}$ os termos de origem tupi/nheengatu presentes na fala do sobrinho do iauaretê. Tal glossário vem preencher uma lacuna apontada por $\mathrm{HC}$ em sua publicação sobre a linguagem em $\mathrm{Meu}$ tio o Iauaretê: "um levantamento completo do glossário tupi usado direta ou veladamente nesta 'estória' seria bastante revelador" (CAMPOS, 1992, p. 60).

\section{ANÁLISE}

No conto Meu tio o Iauaretê, GR utiliza uma engenhosa mescla de tupi e português para representar a transformação do narrador-onceiro em jaguar. Esse personagem é marcado pelo hibridismo, pela mestiçagem, em vários níveis ou aspectos de sua constituição: filho de pai branco e mãe indígena, o homem-onça, amigo e inimigo, fala um português mesclado com tupi (sendo a língua indígena associada no conto à fala dos felinos: o jaguanhenhém). Como é típico da escrita roseana, o texto é repleto de brincadeiras, jogos, sugestões e possíveis relações entre palavras e frases, cunhados das mais variadas formas.

Já no começo da obra, quando o narrador fala de seu finado companheiro de rancho, o preto Tiodoro, lemos: "Preto morreu. Eu cá sei? Morreu, por aí, morreu de doença” (RoSA, 2007, p. 192). No trecho, é clara a ambiguidade da pergunta "Eu cá sei?", que sugere também a leitura "Eu

[4] Neste trabalho os termos "tupi", "LGA" - ou simplesmente "língua geral" - e "nheengatu" serão utilizados como nomeações que se acumulam ao longo dos períodos evolutivos do idioma, ou seja, o nheengatu poderá ser chamado de "tupi" ou "LGA", mas o tupi antigo não será nunca referido por "LGA" ou "nheengatu".

[5] Cf. Apêndice 1 - Glossário dos termos de origem tupi em Meu tio o lauaretê. 
cacei?". Isso fica mais evidente conforme avançamos no texto, percebendo a tentativa inicial do rancheiro de se eximir das mortes humanas por ele citadas, até que por fim confessa sua participação nos óbitos, sendo que em alguns casos, como no mencionado acima, teria literalmente caçado a vítima, durante sua transformação em onça.

Algumas vezes, entretanto, os jogos de palavras envolvendo o tupi não são recuperados por meio de equivalências na língua portuguesa, o que justifica um exame mais detalhado, capaz de elucidar a lapidação da rica linguagem do texto e até mesmo sugerir possíveis interpretações que emergem desse amálgama luso-tupínico.

\subsection{O tupi no jaguanhenhém: a diversidade dos hibridismos ${ }^{6}$}

A mescla entre idiomas aparece, por exemplo, em termos como "munhamunhando" e "mucunando", nos quais o autor utiliza o gerúndio do português sobre temas verbais do nheengatu: munhamunhã (zombar, escarnecer); mucuna (engolir). Em outros casos, GR brinca com a semelhança entre termos de ambas as línguas, pontuando toda a obra com, sobretudo, pequenas palavras e interjeições que acessam significados nos dois universos linguísticos. Entre eles podemos citar o reincidente será, termo idêntico a uma partícula que serve para marcar interrogações no nheengatu (oriundo do serã, do tupi antigo), e que pode desempenhar função similar no português brasileiro. Além dessa palavra, o narrador também marca algumas de suas perguntas com ta-há, outra partícula interrogativa do nheengatu - tahá ou taá-, que pode entrar em ressonância com o "tá?", comum nos finais de questões no português do Brasil. Vale ainda citar a interjeição "ixe", que se confunde por vezes com o pronome indígena ixé (eu); n't, n't e ti reverberam, por sua vez, a negação em nheengatu - inti, nti ou ti -, bem como lembram o muxoxo "tsc, tsc", utilizado com frequência nas histórias em quadrinhos, indicando um sinal de decepção ou reprovação a algo. Outros casos análogos podem ser consultados no glossário, assim como

[6] Não há uma grafia oficial ou unificada para o nheengatu, tampouco para o tupi antigo. Neste trabalho a multiplicidade de grafias dos termos tupis ficará bem evidente, pois apesar dos riscos de confusão que tal diversidade pode gerar, pareceu-nos que criaríamos tanta ou mais dificuldade se pretendêssemos homogeneizar a ortografia. Quando nos referimos a termos utilizados por GR, tentamos manter uma grafia semelhante à sua. As citações de outros autores, evidentemente, vêm com suas grafias originais. $\mathrm{O}$ acento circunflexo sobre as vogais i e u não terá nunca valor tônico nos vocábulos tupis deste artigo: em explicações e exemplos nos quais empregamos o tupi antigo, utilizamos, por vezes, î e û para marcar as semivogais. O y que aparece em vocábulos do tupi antigo é uma vogal média, cujo fonema correspondente encontra-se entre o do $i$ e o do $u$. No nheengatu, o y aparece ora como a representação de um resquício do fonema do tupi antigo, ora como a marca da semivogal $i$, dependendo da ortografia utilizada pelo autor citado. 
as interjeições peculiares ao nheengatu (embora algumas delas tenham entrado no português de algumas regiões da Amazônia), como o uso da exclamação de repulsa axi, muitas vezes repetida pelo caçador de onças.

Para darmos outro exemplo de uma brincadeira com signos linguísticos que repercutem nos dois idiomas, podemos citar a continuação da explicação que o narrador tece no começo do conto, sobre a morte do preto Tiodoro: “(...) morreu de doença. Macio de doença” (RosA, 2007, p. 192). A palavra maaci, ou maci, significa "doente" em nheengatu, assim, nesse trecho, a autotradução típica da narração do onceiro camufla-se pela desvirtuação do termo tupi num significante similar da língua portuguesa, o que confere uma linguagem poética ao sertanejo. Da mesma forma, o nheengatu está também latente em outras palavras ou expressões do vocabulário do caçador, que a primeira vista podem parecer puras construções do português. Um bom exemplo é a expressão "boca-torta”, utilizada pelo narrador como sinônimo ou alcunha do Diabo. Esta é exatamente a tradução literal de Îuruparĩ (do tupi antigo, îuru "boca" + parĩ "torta"), entidade tupi cujo nome os missionários utilizaram, especialmente na região norte, para traduzir o conceito de Diabo presente na cosmologia cristã. Esse termo carrega até hoje, em nheengatu, a acepção de Diabo7.

Ainda mais camuflado está o tupi no nome "pedra-morta", que segundo o onceiro situa-se no meio da vereda onde a onça Papa-Gente costuma beber água. Essa pedra serve de suporte para o felino, que nada até a rocha e pisa sobre ela, parecendo, assim, que "tá em-pé dentro d'água" (RosA, 2007, p. 218). O sentido por trás do termo "pedra-morta", literalmente, emerge do tupi: itá-byra significa "pedra emersa", "pedra erguida", "pedra levantada" (itá "pedra" + byra "emersa, levantada, erguida") ${ }^{8}$. Este seria um nome adequado a uma pedra cuja superfície se sobressai, atingindo a lâmina d'água, no meio de uma vereda. Agora, o termo ambyra, que assumiu a forma ambira no nheengatu, significa "finado, morto", e, assim, itá-ambyra ou itá ambira significaria "pedra morta". Aqui, portanto, GR joga com o efeito causado por uma pequena corrupção do termo tupi, que altera seu significado numa forma que é própria deste idioma, pela semelhança fonológica entre vocábulos que em outras línguas, como é o caso do português, não teriam qualquer relação.

[7] Além desse significado atrelado ao Diabo da cosmologia cristã, lurupari nomeia uma entidade mítica ou religiosa presente em muitas narrativas amazônicas, conhecida em português por Jurupari. Na realidade, tratam-se de várias entidades, de tradições culturais distintas, porém portadoras de características em comum, todas nomeadas por um só termo na língua geral.

[8] Esta é a etimologia da cidade mineira de Itabira, onde nasceu o poeta Carlos Drummond de Andrade. 
Além desses exemplos, nota-se uma correspondência velada entre o sistema numérico do tupi e os nomes dos números, em português, utilizados pelo narrador para comunicar ao interlocutor quantas onças já havia matado: "Cê sabe contar? Conta quatro, dez vezes, tá í: esse monte mecê bota quatro vezes" (RosA, 2007, p. 195). Havia no tupi antigo apenas nomes para os números de um a quatro. Após o contato com os europeus, sabe-se que quando era necessário fazer referência a quantidades maiores, eram utilizados circunlóquios como xe pó (minhas mãos) para se referir ao número dez e xe pó, xe py (minhas mãos, meus pés) para o número vinte. $\mathrm{O}$ sistema numérico do nheengatu provém dos antigos circunlóquios tupis, visto que os números com nomes próprios que organizam toda a contagem, continuam a ser apenas os de um a quatro (iepé "um"; mukũi "dois"; musapíri "três"; irundi "quatro"). ${ }^{9}$ A estes se soma a utilização da palavra $p u$ (mão), que indica o número cinco e que por meio de multiplicações (mukũi pu, "duas mãos" $\rightarrow$ "dez") e somas (pu mukũi, "mão (e) dois" $\rightarrow$ "sete") permite que se exprimam quantidades maiores. A fala do caçador constitui-se num circunlóquio no qual a repetição de cálculos envolvendo números pequenos permite que seja atingida a quantidade pretendida (cento e sessenta), lembrando assim o sistema numérico do tupi. Outra passagem na qual o tigreiro transparece um apego aos numerais originalmente presentes no tupi, recorrendo à utilização da soma para expressar uma quantidade maior, encontra-se neste excerto: "Mecê olha, o sejuçú tem quatro estrelinhas, mais duas" (RosA, 2007, p. 221).

Outra característica marcante do tupi, seja na variante antiga, falada pelos indígenas da costa litorânea, ou na LGA, presente ainda na variante atual do Rio Negro, é a reduplicação de verbos e adjetivos. A reduplicação dos verbos geralmente leva seu significado a um aspecto frequentativo. Vale dizer que se o vocábulo for paroxítono, a última sílaba, átona, cai no primeiro termo da reduplicação. Podemos citar exemplos presentes no conto: mundéu (enfiar, meter / vestir) $\rightarrow$ mundéu-mundéu (ficar enfiando, enfiar repetidas vezes / ficar vestindo); sacêmo (gritar, gemer) $\rightarrow$ sacê-sacêmo (ficar gritando, ficar gemendo, gritar repetidas vezes). O onceiro, em sua fala, não se limita a reduplicar termos tupis, utilizando o mesmo procedimento com palavras do português, o que, temos de admitir, não

[9] Símpson fornece num apêndice de sua gramática (Simpson, 1955, p. 125) nomes para os números de um a dez, a partir dos quais se organizaria um sistema decimal em nheengatu. Os nomes que ele fornece para os numerais de seis a dez, no entanto, são de origem incerta, e não encontramos na literatura outras referências à utilização de tais nomes associados aos algarismos. São, além do mais, totalmente desconhecidos dos atuais falantes de nheengatu do Rio Negro. Era, provavelmente, um sistema de circulação muito restrita, podendo tratar-se até mesmo de uma proposta do autor a ser incorporada na língua e não da descrição de um sistema que ele presenciou em uso. 
é de todo estranho ao português brasileiro, sobretudo em suas variantes orais. A reincidência, contudo, chama a atenção, bem como a variedade de formas como ocorre: "Tapão, tapeja", "pula pulão", "anda andando", "mião-miã", "cheirou, cheira-cheirando" (RosA, 2007, pp. 199, 201, 203, 208 e 207). A mistura de português e tupi ganha um aspecto jocoso e gracioso em trechos como: "não cavacava chão pra tirar mandioca" (RoSA, 2007, p. 230). Nesse caso, a reduplicação do verbo cavar alude ao verbo cavoucar (não cavacava $\rightarrow$ não cavoucava).

No caso dos adjetivos, a reduplicação, no tupi, geralmente indica uma forma superlativa, significa um aumento na intensidade da característica correspondente a tal adjetivo. GR explora esse procedimento não apenas reproduzindo a forma indígena porã-poranga, mas cunhando um equivalente com palavras do português, que é muito repetido ao longo da obra: "bom-bonito" (e seu correspondente feminino "boa-bonita"). A eficácia dessa irreverente tradução poética vale-se do fato de que poranga, que tem geralmente o significado de "bonito", "belo", no tupi antigo, passa a abarcar também, no nheengatu, a acepção de "bom" e até mesmo a do advérbio "bem". A abrangência semântica de um mesmo vocábulo do nheengatu, que originalmente corresponde a "bonito", mas passa a ser usado para qualificar algo que é "bom" ou uma ação que é "bem" executada, deixa também seus rastros em outras falas do narrador mestiço: "É bom. Fumo muito bonito, fumo forte."; "Que cheira bom, bonito, é carne."; "(...) com as pintinhas pretas bubuiando bom (...)"; "Mata um, mata bonito!” (RosA, 2007, pp. 193, 193, 207 e 220).

Passando a mais um elemento bastante atrelado à oralidade, cumpre analisar o aproveitamento morfo-fonológico de que GR faz do sufixo diminutivo "-im", típico do dialeto mineiro - "pouquim", "devagarim", "mansim", "dinheirim", "espelhim", "sozim", "porco-espim", "Tiaguim"-, associado ao sufixo -ĩ, morfema correspondente ao diminutivo em tupi: jaguaraim $\longrightarrow$ "oncim".

Ainda quanto a aspectos fonológicos, notamos que alguns nomes de personagens do conto são, na realidade, nomes próprios tradicionais da língua portuguesa, adaptados à fonologia do nheengatu: Uarentim (de "Valentim"), Riopôro (de "Leopoldo"), Rauremiro (de "Valdemiro"), Rima Toruquato (de "Lima Torquato"). Nesses nomes próprios percebemos alterações fonéticas similares às ocorridas com termos do português que entraram como empréstimos na LGA. Como esse idioma não permite certos encontros consonantais e não possui alguns dos fonemas presentes na língua portuguesa, alterações são necessárias para permitir que palavras "estrangeiras" se adequem a seu sistema fonológico. Entre os fonemas que não integram a LGA podemos citar aqueles que 
representamos em português pelas letras "v", "l", "z" e "d" (há no tupi apenas o que representamos por "nd", mas não pelo simples "d"). Sendo assim, encontramos na LGA, entre outros, os seguintes empréstimos: panéra (de "panela"); cauaru (de "cavalo"), curuçá (de "cruz"), xirura (de "ceroula", porém significando "calça"), camarara (de "camarada"), surara (de "soldado"). Os nomes próprios citados acima, conforme fica claro na confrontação com os empréstimos mencionados, não passam de versões dos nomes portugueses aqui sugeridos, com a substituição das letras "v", "l" e "d" por outras letras cujos respectivos sons se adequam à fonologia da LGA. Talvez num processo análogo, porém resultando numa adaptação fonológica incompleta, tenha sido cunhado o nome Siruvéio (de "Silvério"). Adaptações parciais podem ser vistas em outros termos presentes no conto, como "curuz", que podemos situar entre "cruz" e curuçá.

Além das características linguísticas aludidas, podemos vislumbrar outras possíveis pistas do nheengatu na sintaxe da narrativa. Um bom exemplo encontra-se neste excerto: "Cê vem, me cheira: tenho catinga de onça? Preto Tiodoro falou eu tenho, ei, ei...” (RosA, 2007, p. 234). A falta da conjunção integrante "que" em Preto Tiodoro falou eu tenho, nos remete à língua geral, que carece de conjunção análoga. Vejamos como ficaria a tradução dessa frase para o nheengatu: Tapaiuna Tiodoro unheé ixé ariku. Fica claro, então, a correspondência entre a sintaxe das duas sentenças: (Tapaiuna/Preto) (Tiodoro/Tiodoro) (unheé/falou) (ixé/eu) (ariku/tenho). Vemos algo análogo nos excertos "Não falei - eu viro onça?" e "Eu falei: eu ajudava, levava." (RosA, 2007, pp. 234 e 233). Outra marca sintática que nos estimula a considerar um substrato gramatical do nheengatu na fala do onceiro é a repetida supressão do verbo "ser", verbo que não existe, por sua vez, no idioma tupi: "Eu sou onça... Eu - onça!"; "Vontade dôida de virar onça, eu, eu, onça grande"; "Eu panema não, eu - marupiara"; "Mecê bom-bonito, meu amigo meu"; "Eu tapijara, sapijara (...)" (RosA, 2007, pp. 204, 223, 227, 213 e 230). Em nheengatu, teríamos, por exemplo: ixé (eu), iauaretê (onça) $\rightarrow$ ixé iauaretê, "eu (sou) onça”.

O caso mais interessante, porém, de possível utilização da sintaxe tupi com o léxico da língua portuguesa, encontra-se no seguinte trecho: "Vem por de dentro. Onça mão - onça pé - onça rabo... Vem calada, quer comer." (RosA, 2007, p. 196). A leitura desse fragmento nos remete a um aspecto da sintaxe típica do nheengatu (e também do tupi antigo), na qual a relação genitiva é formada pela justaposição de termos na ordem contrária àquela em que eles apareceriam numa sentença da língua portuguesa: iauaretê (onça), pu (mão); então, iauaretê pu $\rightarrow$ "mão de onça". Sendo assim, se traduzirmos apenas as palavras do nheengatu para o português, mantendo a sintaxe daquele idioma, teremos: 
iauaretê pu $\longrightarrow$ "onça mão". O mesmo vale para "onça pé" - iauaretê pi - e "onça rabo" - iauaretê ruaia. A partir da interpretação proposta, teríamos aí híbridos português/nheengatu, o primeiro ocupando o nível semântico e o segundo o nível sintático. Uma "tradução completa" para a língua portuguesa nos levaria, pois, à sequência de relações genitivas: "mão de onça - pé de onça - rabo de onça". Vemos, então, como a língua aparece no conto como o meio em que se dá a transformação: a mescla de tupi com português simbolizando a duplicidade da condição do protagonista homem-onça. Ao relermos a mencionada passagem efetuando a "tradução" aqui proposta, temos: "Vem por de dentro. Mão de onça - pé de onça - rabo de onça... Vem calada, quer comer". Assim, essa passagem, além da manifesta menção à onça que vem por dentro do mato, pode nos remeter também à fera que vem das entranhas do sobrinho do iauaretê, transformando seus membros e sua linguagem. Podemos comparar o trecho analisado com o início de sua transformação em jaguar, que ocorre mais adiante no conto: "Tava urrando calado dentro de em mim... Eu tava com as unhas...” (RosA, 2007, p. 223).

\subsection{O Sejuçu ${ }^{10}$}

Saindo agora das considerações envolvendo influências do tupi no nível sintático da narração, voltemo-nos para um termo da língua geral cuja rede de significações é muito grande e cujo conhecimento influência bastante na interpretação de um trecho da narrativa. Trata-se do sejuçu, nome atribuído pelos falantes da língua geral à constelação das plêiades, conjunto de estrelas muito importante na astronomia de diversas etnias indígenas do território brasileiro (e também de outras etnias mundo afora), cuja movimentação no firmamento era utilizada para marcação temporal. Prestemos atenção ao seguinte excerto: "Mecê olha, o sejuçú tem quatro estrelinhas, mais duas. A'bom: cê enxerga a outra que falta? Enxerga não? A outra - é eu..." (RosA, 2007, p. 221).

Ao sejuçu associam-se muitos mitos e lendas, alguns dos quais foram coletados, em nheengatu, na segunda metade do século 19, pelo general Couto de Magalhães e também pelo biólogo Barbosa Rodrigues, que os publicaram com tradução para o português, respectivamente, nas obras O Selvagem e Poranduba Amazonense, em meio a outras narrativas em 
língua geral ${ }^{11}$. A narrativa que melhor nos ajuda a interpretar o fragmento acima, entretanto, foi ouvida durante trabalhos de campo na região do Alto Rio Negro, quando conversávamos com a professora Celina Menezes da Cruz , falante de nheengatu. Debatíamos sobre diversos assuntos e em algum ponto da conversa abordamos o siiuci - como é chamado o sejuçu no nheengatu da região - e o número de estrelas que o compõem. A professora nos disse, então, que normalmente conseguimos contar apenas seis estrelas quando olhamos em direção a essa constelação, já que uma delas aparece muito pequenina no firmamento. Quando, porém, olhamos para o siiuci e contamos sete estrelas, significa que nossa morte está próxima: é sinal de que iremos morrer até o fim do ano. Ela ainda acrescentou que certa vez estava sentada à noite na companhia de um de seus irmãos, ao que este se colocou a contar o número de estrelas do sejuçu e chegou ao fatídico número sete. Dentro de pouco tempo, segundo a professora, ele viria a falecer, pelo que nos reforçou, em sua narração, a validade dessa tradição. No trecho em questão, portanto, o onceiro dá mais uma indicação do iminente ataque ao interlocutor, como bem a qualquer pessoa que cruze seu caminho: quem o vê está com os dias contados.

Ainda em relação ao sejuçu, nas lendas recolhidas por Barbosa Rodrigues e Couto de Magalhães, podemos identificar possíveis diálogos com o conto de GR. Na narrativa intitulada Cyiucé Yperungaua (A Origem das Plêiades) (RodRigues, 1890, p. 257), sete crianças são criadas desde o nascimento pela "mãe das onças". Já mais crescidas, elas resolvem vingar a falecida mãe biológica, que havia sido devorada pelos jaguares. Após matarem os felinos no meio dos quais haviam se criado, vão para o céu e viram as plêiades.

Na lenda intitulada Tamecan ${ }^{12}$ (RodRigues, 1890, p. 223), por sua vez, um casal tem sete filhos, os quais estão sempre famintos e choram continuamente pedindo comida aos pais. Diante da incapacidade destes de saciarem o infinito apetite dos filhos, os pequenos decidem subir aos céus para serem estrelas, transformando-se então nas plêiades. Neste momento há uma única e breve menção a um "tio" das crianças, que não é mais detalhado ao longo do pequeno texto: "nós já vamos indo para o céu

[11] Além das lendas que tratam mais especificamente do sejuçu, esta constelação tem também importante presença em outras narrativas, como as interessantes lendas sobre o Jurupari, nas quais ceucy (sejuçu) é a mãe virgem do personagem mítico, que engravidou pelo sumo de uma fruta (uacu, segundo as versões do Rio Negro). A mais famosa dessas lendas foi publicada em italiano por Ermanno Stradelli, no ano de 1890, sob o título de Leggenda dell'Jurupary. Os originais em nheengatu infelizmente se perderam. 
ter com nosso tio para sermos estrelas". A relação que vemos aqui entre ser uma estrela do sejuçu e buscar contato com o "tio" não é estranha à composição de GR, afinal, como vimos acima, a autoidentificação do onceiro com uma estrela desse grupo é uma velada menção à sua natureza de jaguar. O termo "tio", por outro lado, que dá título à obra de GR é, na verdade, uma referência ao conjunto das onças, tratando-se também de uma alusão ao parentesco do narrador com os jaguares: "Eh, onça é meu tio, o jaguaretê, todas" (RosA, 2007, p. 206). Assim, a aproximação com "o tio" e o ato de assumir a forma de uma estrela do sejuçu são processos equivalentes em Meu tio o Iauaretê.

Se as crianças da lenda Tamecan estavam constantemente famintas, aquelas de Cyiucé Yperungaua, abordada anteriormente, choravam pedindo comida à mãe, quando ainda estavam em seu ventre. A questão da fome, ou gulodice, mostra-se frequente nas narrativas sobre as plêiades. Numa narrativa colhida e publicada por Couto de Magalhães (1975, p. 270), a Ceiuci (variante do nome "sejuçu") é representada por uma velha gulosa que persegue o protagonista a fim de devorá-lo. Em outra das lendas coligidas por Barbosa Rodrigues (1890, p. 221), intitulada simplesmente Cyiucé, a sede é a sensação atrelada à constelação. Rodrigues chega a sugerir em nota uma etimologia para cyiucé como "a mãe dos que têm sede", o que é duvidoso enquanto informação linguística, mas pode sim ter influenciado seus leitores. A fome, a sede, a vontade de devorar, são elementos que permitem, portanto, mais uma relação entre o sejuçu e a natureza felina do tigreiro.

\subsection{Suaçurana, jagueretê e os nomes próprios}

Passemos agora à analise de outro termo significativo da obra, qual seja, a sempre referida suaçurana, literalmente "falso veado", "veado espúrio" (suaçu "veado" + -rana "falso, espúrio, o que parece com algo mas não é") ${ }^{13}$. O narrador, mais de uma vez, afirma que ela não é seu parente

[13] O sufixo -rana, da língua geral - proveniente do adjetivo ran, do tupi antigo - entrou para o português brasileiro, tomando parte na composição de muitas palavras. Ele marca presença de forma especial na fala dos ribeirinhos da região amazônica. Para mais informações, cf. Azevedo, Orlando; Margottı, Felício. "O sufixo -rana no português falado pelo caboclo amazonense". In: Revista Alfa, 56 (2). São Paulo, 2012, pp. 611-621. Esse sufixo é utilizado outras vezes por GR, como em Sagarana, nome de um de seus livros. Sagarana é um hibridismo de escandinavo antigo (DıııonÁrı Aulete..., c[201-]) e tupi - saga (narração ficcional ou histórica com muitas aventuras) + -rana = "saga falsa, espúria, adulterada, o que parece saga mas não é”. Também se identifica esse sufixo em Riobaldo Tatarana, como é chamado o protagonista do livro Grande Sertão: Veredas (tatá (fogo) + -rana = "o que parece fogo mas não é"). O nome "tatarana", no português brasileiro, é variante de "taturana”, que provém do tupi tataûrana (falso fogo escuro) (NAVARRo, 2013, p. 467). 
e chega a transparecer certo rancor por esse animal: "Mas suaçurana mata anta não, não é capaz. Pinima mata; pinima é meu parente!..."; "Suaçurana esbarrou. Ela é a pior, bicho maldoso, sangradeira."; "Mas suaçurana não é meu parente, parente meu é a onça preta e a pintada..."; "Suaçurana tem nome não. Suaçurana parente meu não, onça medrosa."; "Só suaçurana é que é pixote, foge, larga os filhotes pra quem quiser..." (RosA, 2007, pp. 193, 208, 209, 213 e 221).

No parágrafo em que o onceiro narra seu primeiro encontro com Maria-Maria, ele sofre uma espécie de transformação interna, arrependendo-se profundamente de ter executado seus parentes felinos. Para matar as panteras, o narrador aproveitava-se de sua condição de semelhante, que lhe possibilitava uma proximidade com as feras, propício para seus ataques-surpresa. O caçador, por assim dizer, era uma "falsa onça", que se aproveitava de sua semelhança para atraiçoar os animais. No momento de seu arrependimento e transformação de sua conduta, ele resolve não mais matar os referidos felinos, abandonando por completo as caçadas aos jaguares. Contudo, justamente nessa passagem, o onceiro vai atrás de uma suaçurana para liquidá-la. Não o faz para aproveitamento de sua pele ou por qualquer outro motivo pragmático, mas movido por raiva, sentimento que ele justifica por causa do estrume que a onça vermelha deixara no local que ele utilizava para dormir. A raiva, no entanto, pode ter outro motivo complementar que não é explicitado por sua narração: a visão da suaçurana pode ativar em sua memória a falsidade que constitui seu próprio sujeito, já que esse animal é o "falso veado" que mata veados, e o narrador-onceiro, a "falsa onça" que mata onças. De fato, quando aniquila a suaçurana, esta havia matado há pouco um veadinho catingueiro. Podemos ver, então, nesse trecho, uma atitude com caráter ritualístico, como é típico dos ritos de passagem: para marcar o momento em que ele assume sua identidade de jaguar, deixando de lado a falsidade que lhe era característica, ele mata aquele ser cujo nome remete a algo espúrio, eliminando, assim, simbolicamente, a sua própria falsidade. Daí suas repetidas objeções ao parentesco que se poderia aludir entre as suaçuranas e ele. Essa passagem marca, dessa forma, um importante momento no que concerne à transformação do onceiro em onça, quando o narrador deixa de ser uma espécie de falso jaguar, para assumir sua identidade felina.

Notemos ainda que se a suaçurana carrega em sua denominação uma marca de falsidade, algo inverso ocorre com a palavra jaguaretê, que designa os felinos com os quais o narrador busca se identificar. $\mathrm{O}$ termo iaguara, ou jaguara, à chegada dos primeiros europeus à Terra de Vera Cruz, denominava a onça. Nos navios do Velho Mundo vieram, 
entretanto, os primeiros cachorros domésticos que pisaram em solo americano, e não havendo nome no tupi para designar aquela espécie desconhecida, por um processo de analogia, esses animais também foram chamados de iaguara, ou seja, receberam a mesma denominação que cabia às onças. No entanto, em muitas situações fazia-se necessário distinguir se se falava de onças ou de cachorros, a fim disso a ambiguidade foi desfeita pelo acréscimo do advérbio eté (verdadeiro, de verdade, real, para valer) à palavra iaguara. Quando se queria, assim, explicitar que o animal designado era a onça, e não o cachorro, dizia-se iaguareté, ou seja, "onça de verdade", "onça verdadeira". Vemos então que no plano linguístico a fixação do onceiro pelos jaguaretês é complementar ao seu desprezo pelas suaçuranas e relaciona-se com a sua busca de uma natureza "pura", "verdadeira", "real”, em oposição a uma "falsa", "espúria", "transitória".

A valorização de uma natureza e personalidade fixas, ou bem definidas, pode ser percebida também no tratamento a respeito dos nomes próprios. Segundo o narrador, os jaguaretês têm nomes próprios, ao contrário das suaçuranas:

"Agora eu não mato mais não, agora elas todas têm nome. Que eu botei? Axi! Que eu botei, só não, eu sei que era mesmo o nome delas." (sobre os jaguaretês) (RosA, 2007, p. 211).

"Sei não. Suaçurana tem nome não. Suaçurana parente meu não, onça medrosa." (RosA, 2007, p. 213).

Os nomes próprios permitem um tratamento individualizado aos jaguaretês: cada um tem uma personalidade, uma história diferente. Já suas primas vermelhas são tratadas de forma genérica e coletiva, como se não possuíssem uma identidade. O nome próprio pode ser entendido como uma marca de coesão da natureza/personalidade, afinal ele abarca sob um único signo as características muitas vezes discrepantes e contraditórias de nossa existência, possibilitando assim que nos concebamos como indivíduos dotados de uma história, como seres possuidores de uma continuidade interior, por mais que complexa. $\mathrm{O}$ onceiro é um ser não só híbrido, mas cindido, já que os conflitos entre suas naturezas confundem-lhe a concepção de si mesmo. Não que ele não possua marcas de uma individualização, mas o que há de sujeito uno no homem-jaguar se torna uma consciência extremamente pesada, um palco de contínuo arrependimento pelas ações que ao beneficiar uma de suas naturezas age contra a outra. A grande polaridade de seu espírito resulta numa fraca aderência a nomes e apelidos, os quais vão se substituindo ao longo de sua vida. Eles mostram-se efêmeros, talvez incapazes de abarcar as contradições e divergências de seu espírito 
sob um único signo. Um nome próprio, por outro lado, ao explicitar o que há de contínuo no ser nomeado, realçando uma consciência de si mesmo como indivíduo, talvez maximizasse o sentimento de culpa e as dores de lamentação do homem-onça. Sendo assim, após inúmeras trocas de nomes e alcunhas, ele acaba ficando como as suaçuranas, ou seja, sem nome algum:

\begin{abstract}
Ah, eu tenho todo nome. Nome meu minha mãe pôs: Bacuriquirepa. Breó. Beró, também. Pai meu me levou pra o missionário. Batizou, batizou. Nome de Tonico; bonito, será? Antonho de Eiesús... Despois me chamavam de Macuncôzo, nome era de um sítio que era de outro dono, é - um sítio que chamam de Macuncôzo... Agora, tenho nome nenhum, não careço. Nhô Nhuão Guede me chamava de Tonho Tigreiro. Nhô Nhuão Guede me trouxe pr'aqui, eu nhum, sozim. Não devia! Agora tenho nome mais não... (RosA, 2007, pp. 215-216).
\end{abstract}

O oposto ocorre com sua amada, que representa de certa forma um ideal perseguido pelo narrador. Esta onça, como se não bastasse possuir um nome próprio, tem-lhe duplicado: Maria-Maria. Tal duplicação, que nos remete ao tupi, parece possuir um efeito hiperbólico de especificação do referente, sugerindo uma equivalência com "Maria de verdade", "Maria verdadeira", "Maria por excelência". Vemos nos jagueretês, portanto, ideais perseguidos pelo onceiro no que diz respeito à determinação de uma individualidade coesa e coerente. As suaçuranas, por outro lado, compartilham com o narrador características que ele repugna em si próprio e por isso ativam sentimentos de desprezo e raiva no homem-onça. Isso se revela, conforme nossos argumentos, tanto nos nomes das espécies como nas presenças e ausências de nomes próprios para seus indivíduos.

Quanto ao nome "Maria", cumpre lembrarmos a importante presença de outras duas personagens femininas estimadas pelo onceiro: "Maria Quirinéia" e a finada mãe do narrador, "Mar'Iara Maria". O nome da última, aliás, possui grande ressonância com aquele da onça amada pelo protagonista. Tal nome, ao que tudo indica, foi inspirado numa oração escrita pelo segundo bispo do Amazonas, D. Frederico Costa (1909, p. 169), em seu manual Elementos Necessários para Aprender o Nheengatú14 ${ }^{14}$ 
Vejamos a primeira estrofe de sua oração Catú reté Rosário (Bendito Rosário), seguido de uma tradução de nossa autoria ${ }^{15}$ :

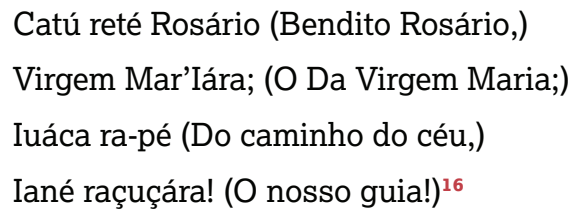

A presença de um elemento cristão vinculado ao nome "Maria", tão reiterado no conto de GR, assim como o é nos textos daquela tradição religiosa, pode abrir caminho a muitas interpretações, as quais nos abstemos de comentar por fugir do objetivo deste trabalho.

Voltando à decisão do onceiro de assumir sua natureza felina, notamos que a sua tentativa de se tornar um "verdadeiro jaguar" gera um processo contrário em relação à natureza humana do protagonista: ele passa a se aproveitar de sua semelhança com os homens para liquidá-los em favor das onças, agindo, assim, como um "falso homem". Seus remorsos, a partir de então, dividem-se, em suas causas, pelas matanças de onças e de seres humanos:

Tou amaldiçoando, tou desgraçando, porque matei tanta onça, por que é que eu fiz isso?! Sei xingar, sei. Eu xingo! Tiss, n’t, n’t!... Quando tou de barriga cheia não gosto de ver gente, não, gosto de lembrar de ninguém: fico com raiva. Parece que eu tenho de falar com a lembrança deles. Quero não. Tou bom, tou calado. Antes, de primeiro, eu gostava de gente. Agora eu gosto é só de onça. Eu aprecêio o bafo delas... Maria-Maria - onça bonita, cangussú, boa-bonita (RosA, 2007, p. 202).

Nesse excerto transparecem os conflitos internos do narrador, que quando está de barriga cheia, provavelmente de carne humana, evita ver gente para não ter de encarar a lembrança de suas aniquilações. $O$ mesmo é demonstrado quando ele se livra do retrato da mulher do preto Tiodoro,

[15] "Bendito Rosário" é a tradução que o próprio Frederico Costa dá ao título da oração, sendo assim, preferimos mantê-lo na tradução do primeiro verso. Traduções mais literais seriam "Rosário Muito Bom”, ou "Rosário Muito Bondoso". O autor fornece a tradução apenas do título. Para a tradução integral da oração, cf. Anexo 1 - Tradução da oração Catú reté Rosário, do bispo D. Frederico Costa.

[16] A versão em nheengatu publicada por D. Frederico Costa é, provavelmente, tradução de um original em português. Encontramos uma oração intitulada "Bendito Rosário" cuja primeira estrofe é bem análoga à do Bispo: "Bendito Rosário / Da Virgem Maria / Caminho seguro / Que à glória nos guia” (BENDITO..., [201-]). 
escondendo-o num oco de pau. Essas passagens ajudam a compreender como o caçador mestiço vivia em meio ao remorso, lutando para se livrar das memórias de suas matanças, diretamente relacionadas à sua natureza híbrida. Isso corrobora a presença de um conteúdo sentimental e simbólico na matança da suaçurana mencionada alguns parágrafos acima, e mostra que tal atitude e a respectiva decisão de assumir sua natureza felina não livraram por completo o narrador-caçador dos arrependimentos e remorsos, que continuam a se acumular, agora devido às suas atitudes traiçoeiras para com seus semelhantes humanos.

\subsection{Os últimos rugidos}

Longe de esgotarmos as possibilidades analíticas do uso do tupi no conto, passemos agora ao seu desfecho. No ápice de tensão entre o narrador e o seu interlocutor, após aquele ter confessado a este a sua participação nos óbitos relatados e ter repetidas vezes implorado para que o visitante guardasse seu revólver, lemos:

Ui, ui, mecê é bom, faz isso comigo não, me mata não... Eu - Macuncôzo... Faz isso não, faz não... Nhenhenhém... Heeé!...

Hé... Aar-rrã... Aaãh... Cê me arrhoôu... Remuaci... Rêiucàanacê... Araaã... Uhm... Ui... Ui... Uh... uh... êeêê... êê... ê... ê... (RosA, 2007, p. 235).

Em meio aos berros-rugidos do homem-onça, alguns dizeres tupis são identificados, como remuaci e rêiucàanacê. $M u a c i^{17}$ é um verbo que possui vários sentidos e dependendo do contexto podemos traduzi-lo por diferentes verbos da língua portuguesa, tais como: "magoar-se", "ficar sentido", "lamentar", "arrepender-se de", "ter pena”, "ter dó”, "ter piedade", "ter inveja de". Precede esse verbo o prefixo número-pessoal re-, de segunda pessoa do singular. No nheengatu tal prefixo pode ser utilizado tanto na forma indicativa como na forma imperativa dos verbos. No segundo segmento, vemos o verbo iucá (matar), precedido do

[17] Este verbo do nheengatu provém do verbo análogo do tupi antigo moasy (invejar / ressentir-se de, levar a mal / sentir a dor de, ter dor por, lamentar / arrepender-se de / fazer sofrer), que resultou no nome próprio de pessoa "Moacir". Este é o nome do filho da personagem principal do romance Iracema, de José de Alencar, que tendo por pai o português Martim, representa a miscigenação entre indígenas e europeus. Alencar apresenta a etimologia "filho da dor" para o nome da personagem, etimologia um tanto imprecisa, já que ao provir do tema verbal moasy em sua forma nominal homônima, poderíamos associá-lo a "lamento", "arrependimento", "o ato de fazer doer", "o que faz sofrer" etc. (NAVARRo, 2013, p. 286). 
mesmo prefixo número-pessoal re- e sucedido pelo advérbio ana (já), o qual é seguido, por sua vez, pelo pronome pessoal de $1^{\underline{a}}$ pessoa ce (me / meu, minha). Vale dizer também que os verbos do nheengatu possuem a mesma forma no presente e no passado. Sendo assim, reiucá ana ce poderia significar "você já me mata" ou "você já me matou". Dessa forma, traduzimos remuaci...rêiucàanacê... como "tenha piedade!... você já me matou...". ${ }^{18}$ Para tal escolha, entre as diversas possibilidades tradutórias, levamos em conta, além do contexto em que a fala/gemido é produzida, o verbete muaci da lista de vocábulos contida na já referida obra de D. Frederico Costa, Elementos Necessários para Aprender o Nheengatú (1909, p. 198). Tudo indica que GR consultou, entre outros materiais, a publicação do antigo bispo do Amazonas, tendo até mesmo transcrito alguns dos verbetes do religioso em suas anotações datilografadas para o estudo do vocabulário a ser empregado no conto Meu tio o Iauaretêt ${ }^{19}$. Frederico Costa escreve em seu vocabulário: "Muaci - Sentir, soffrer, ter pezar - Re-muaci - Tem piedade!".

Nessas últimas linhas, podemos ver também algumas interjeições do nheengatu, como Heeé!, que parece transplantada da gramática de Símpson (1955, p. 111) (até no número das vogais "e"), na qual o autor manauara atribui-lhe o significado de "sinal de terror, pânico". Símpson também lista a interjeição araán (1955, p. 111), citada no compêndio gramatical de Faria (1858, p. 23), na forma arahãi, que indicaria profunda tristeza ou saudade. Essa interjeição aparece em dicionários da língua portuguesa, que abonam sua origem tupi, na forma "araã" (FERREIRA, 2014). Impossível de não notarmos a semelhança com alguns dos sons emitidos pelo onceiro em meio aos seus berros.

Mais revelador e interessante, entretanto, é o trecho "cê me arrhoôu". Para sua análise, saiamos a princípio das considerações em torno do

[18] A utilização do pronome ce nessa posição é pouco usual na literatura escrita em nheengatu, em que vemos com mais frequência o pronome ixé. O pronome ce, quando utilizado como objeto direto de um verbo transitivo tende a vir antes do verbo, que na maioria das vezes vem então sem seu prefixo número pessoal. O motivo da sentença cunhada por GR fugir ao que temos de mais usual na literatura é de difícil compreensão, podendo ser algo proposital ou não. Vale citar a hipótese, ainda que bastante especulativa, de que o uso do pronome ce nessa posição provoque uma ressonância com o pronome acé, do tupi antigo, que tem por significação: "nós", "nós todos", "a gente". Nesse caso, teríamos mais um exemplo da dificuldade do narrador em se sentir como indivíduo, já que em suas derradeiras palavras o "eu" ecoa um "nós" (ou o "me" ecoa um "nos"): rêiucàanacê $\rightarrow$ reiucá ana ce (você já me matou) / reiucá ana acé (você já nos matou). A segunda frase seria fruto de uma linguagem mais autoral e fictícia, pois o pronome acé, do tupi antigo, não penetrou no nheengatu, que claramente predomina nessas falas finais, tanto em sua semântica como em sua sintaxe.

[19] As anotações consultadas fazem parte do Fundo João Guimarães Rosa do Arquivo IEB-USP. O código de referência correspondente a esse material é JGREO04,01. 
nheengatu e voltemo-nos um momento para a língua portuguesa. $\mathrm{O}$ aparente gemido arrhoôu pode remeter à conjugação da segunda pessoa do singular no pretérito perfeito do verbo "arar" - arou -, que tem como um de seus significados "ferir"20. Considerando que "cê" é uma contração do pronome de tratamento "você", teríamos o seguinte significado para o trecho acima: "você me feriu". Obtemos assim, como a tradução completa das falas captadas em meio às interjeições tupis: "você me feriu... tenha piedade!... você já me matou...".

A língua portuguesa não esgota, contudo, as possibilidades de interpretação dos dizeres "cê me arrhoôu". Voltando ao nheengatu, que é o idioma que prevalece nas últimas verbalizações do narrador, podemos estabelecer uma tradução do trecho, interpretando-o como: cemiara oú, ou seja, "ele(a) come a sua presa", "ele(a) come a presa dele(a)". Somos, assim, levados à seguinte tradução alternativa para os mesmos dizeres vertidos acima: "ela come a presa dela... tenha piedade!... você já me matou...". O onceiro, portanto, parece fazer uma última súplica, pedindo talvez por sua vida, mas, principalmente, pela vida de Maria-Maria. Ao ser atingido e estar prestes a morrer, ele teme que seu assassino dê o mesmo destino para sua amada, e em meio à agonia final lança um pedido desesperado: seu argumento é de que ela, Maria-Maria, come sua presa, ou seja, não mata por maldade e sim por necessidade. O sujeito híbrido continua sua fala com um pedido de piedade e uma constatação que pode ser compreendida como um rogo de "basta" para a reação de seu interlocutor: "você já me matou", ou seja, "agora basta, poupe Maria-Maria".

O narrador do conto morre como onça, falando seu característico jaguanhenhém. Seus urros são palavras que reproduzem a agonia cifrada dos felinos abatidos, conforme o próprio onceiro já havia presenciado tantas vezes: "Cê quer saber de onça? Eh, eh, elas morrem com uma raiva, tão falando o que a gente não fala..." (RosA, 2007, p. 198). Por meio de uma linguagem "que gente não fala", já que o tupi, na obra, é associado ao idioma dos jaguares, o onceiro pronuncia súplicas muito condizentes com o sofrimento humano em relação à morte e à preocupação com os entes queridos; assim, seu hibridismo perpetua-se até os momentos finais, sendo sua sina a indefinição de sua natureza. 


\section{CONCLUSÃO}

O jaguanhenhém, a linguagem do iauaretê, analisado brevemente ao longo deste estudo, é uma linguagem travestida, pois, como vimos, em alguns momentos, os semelhantes aspectos sonoros e gráficos entre as duas línguas - o português e o tupi - evocam significados distintos nos dois códigos linguísticos: hein? e nhém?; macio e maci; cê me arou e cemiara oú.

Como HC já dissera em seu ensaio, a linguagem do iauaretê "ora vela, ora revela" (CAmPos, 1992, p. 59), ou seja, apresenta informações latentes e patentes, mescladas das mais variadas formas. É certo que o embasamento que fundamenta as escolhas para as interpretações menos evidentes prescinde de certo conhecimento linguístico do tupi antigo e do nheengatu, assim como de elementos culturais a estas línguas relacionados.

A respeito da tradução dos últimos brados-rugidos do homem-onça fornecida por $\mathrm{HC}$ em uma nota de seu ensaio, constatamos que o seu esforço careceu de conhecimentos linguísticos que pudessem auxiliá-lo em uma interpretação satisfatória do excerto, fato que não esvazia o valor de seu ensaio, visto que o próprio crítico reconheceu as limitações de seu trabalho, aventando para a necessidade de estudos mais aprofundados sobre a linguagem do iauaretê ${ }^{21}$. I

[21] Segundo HC, "'Remuaci' pode ser visto como a montagem de 'rê' ('amigo') + 'muaci' ('meio irmão'); 'Reiucàanacê' pode ser desdobrado em 'rê' ('amigo') + 'iucá' ('matar') + 'anacê' ('quase parente'). O homem-onça, vendo-se perdido, apela para seu interlocutor, porém já em língua-de-jaguar, com sons que querem inutilmente dizer: 'Não me mate! Sou seu amigo, meio irmão, quase parente!'” (1992, p. 62). HC, na verdade, acerta apenas na identificação do tema verbal iucá (matar). É um tanto custoso compreender de onde ele tira suas traduções. Tastevin (1923, p. 635) anota muacǐkĭwera (meio-irmão), que seria mais bem grafado muacycuera, de mu (irmão) + acycuera (pedaço, parte). Daí, provavelmente, decorre a tradução de HC para muaci. O mais próximo que podemos imaginar para a tradução que HC realiza de rê é o substantivo irũ, do tupi antigo, que significa "companheiro". Quanto a anacê, ele talvez tenha interpretado como proveniente do sufixo, em geral agregado a bases verbais, -suer ou -sué (quase, por pouco que) do tupi antigo, unido ao substantivo anama (família, familiar, parente), construção que não nos parece plausível. A negação que vem em sua tradução - "Não me mate!" - surge misteriosamente, não tendo ele a atribuído a nenhum constituinte da fala do onceiro. 


\section{APÊNDICE 1 - GLOSSÁRIO DOS TERMOS DE ORIGEM TUPI EM MEU TIO O IAUARETÊ}

Idiomas - [TA]: palavra em tupi antigo; [LGA]: palavra em língua geral amazônica; [NHE]: palavra em nheengatu; [GUA]: palavra em guarani; [PT]: palavra em português; [PT/T]: palavra em português, mas de origem tupi

Fontes - (GR): anotações consultadas em manuscritos e dactiloscritos de Guimarães Rosa ${ }^{22}$; (CA): palavra consultada no dicionário digital Caldas Aulete; (NA): palavra consultada no Novo Dicionário Aurélio da Língua Portuguesa

Sobre os procedimentos adotados neste glossário:

- Colocaremos, nas entradas do glossário, uma sigla indicando a que idioma as palavras correspondem. Para isso, utilizaremos as siglas referentes aos idiomas: [TA], [LGA], [NHE], [GUA], [PT] e [PT/ T] $]^{23}$.

- Algumas vezes forneceremos outras grafias às palavras abonadas, devido a alterações nos termos tupis feitas por GR em suas utilizações no conto, bem como quando citamos autores que as registram, ou quando fornecemos informações relevantes para a etimologia de alguma palavra.

- As fontes consultadas ou referências bibliográficas aparecerão sempre após o registro de uma palavra ou de uma citação. Não especificaremos a referência de termos que estão em todas ou na maioria das fontes consultadas, mas apenas os que constam em fontes específicas.

- Quando, para um mesmo vocábulo, fornecermos sentidos distintos, utilizaremos o sinal gráfico de barra - / - para separá-los.

[22] Os materiais por nós consultados pertencem ao Fundo João Guimarães Rosa do Arquivo IEB-USP. Os códigos de referência correspondentes a esses materiais são JGREO04,01, JGRM07,01 e JGRM07,02.

[23] A distinção entre os diferentes estágios da língua tupi, de sua forma antiga (séculos 16 e 17) até o nheengatu, nem sempre é muito clara na simples observação dos vocábulos, o que nos leva a realizar algumas simplificações. Como nheengatu, estamos considerando o modo pelo qual as palavras foram grafadas e os sentidos a elas atribuídos a partir de meados do século 19. Quando necessitamos recorrer a grafias e acepções mais comuns em períodos anteriores, atribuímos o vocábulo ao tupi antigo. A sigla LGA, por sua vez, será utilizada apenas quando citarmos obras que tratam da língua veiculada num período intermediário entre o tupi antigo e o nheengatu (século 18 e início do século 19), não sendo necessariamente reiterada nas diversas ocasiões em que os registros concernentes a tal período assemelham-se àqueles referentes aos outros estágios evolutivos do tupi. A respeito do idioma guarani, tendo em vista seu parentesco com o tupi, atribuímos-Ihe apenas as palavras que Ihe são particulares, mas não aquelas que coincidem com termos registrados em obras sobre o tupi. 
- Quando adicionarmos informações ao significado das entradas, utilizaremos o sinal gráfico das chaves -\{\} - para fazê-lo.

- Quando acharmos necessário, forneceremos uma nota com informações que se relacionam direta ou indiretamente à acepção do vocábulo analisado.

ã, ã-ã: [TA] aan: não

abaeté: [TA] homem honrado, digno, de bem, de valor, corajoso ${ }^{24}$

abaúna: [TA] homem negro

acutia: [TA e NHE] akuti: cutia

a-hé, a-é: [NHE] ahé, aé: ele, ela / "a-é: sim" (GR) \{provavelmente do

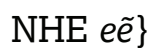

anhum, nhum: [NHE] só, sozinho

apá, pá: [NHE] apa: ombro / [PT] apá, pá: pode significar "peça de carne bovina de segunda categoria, tirada da parte mais larga e carnuda da pata das reses" (CA)

apê!: [NHE] apé: interjeição de grandeza (SímPSON, 1955, p. 111); interjeição de grandeza: "colosso!, maravilha!" (DA Silva, 1945, 166)

Apiponga (nome de onça): [NHE] inchado, empachado araã: [NHE e PT/T] araán: interjeição de profunda tristeza, de saudade (Símpson, 1955, p. 111); arahãi: diz quem sente saudade (FARIA, 1858, p. 23); araã: "[Do tupi] Interj. Bras. Indica surpresa e saudade" (NA) aruê: interjeição cujo sentido não encontramos nas obras pesquisadas atié, atiê: [NHE] athié!: sinal de reprovação (SímpSon, 1955, p. 111)

atimbora: [NHE] sinal de enfado: "Mude-se! Não me consuma" (SímPSon, 1955, p. 111)

atiúca: [NHE] athiuncá!! sinal de lástima (SímPSon, 1955, p. 111); athúnca: interjeição de lástima e compaixão: "coitadinho!, bonitinho!, pequenino!" (DA SiLVA, 1945, p. 166)

auá?: [NHE] quem?

axi, axe: [NHE] exclamação de repulsa (STRADELLI, 2014, p. 329); achy: sinal de nojo, asco, desprezo (Símpson, 1955, p. 111) \{Hoje, no Rio Negro, pronuncia-se "adi"\}

Bacuriquirepa: [talvez do NHE] bacuri + quirera: quirera de bacuri, farelo de bacuri 
Beró (antropônimo): lembra o termo peró, utilizado no tupi antigo para designar os portugueses

çacyara: [NHE] triste

caipora: [NHE e PT/T] infeliz, cheio de apertos, de constrangimentos

(STRADELli, 2014, p. 333) / "um caboclinho muito pequeno, magro, apenas de tanga, com o corpo pintado de urucũ e com uma urupema à cabeça" (GR)

cãuinhuara: [NHE] bebedor de cachaça, aquele que bebe muita cachaça; "cãohim-uára - Bebedor de cachaça" (CoSTA, 1909, p. 182)25

cangussu: $[\mathrm{PT} / \mathrm{T}]$ \{de akanga + guasu: cabeça grande, cabeçuda\} variedade de onça

capão: [PT/T] \{de ka'apa'ũ: intervalo da mata\} "trecho pequeno de mata arbórea em meio a um campo" (CA)

capoama: [NHE] ilha

capoeira: [PT/T] \{de ka'a-puera: mata que já era, o que foi mata\} "terreno com mato, cuja vegetação anterior foi roçada ou queimada para o cultivo da terra ou para outro fim" (CA)

caruca: [NHE] urinar, mijar

cataca: [NHE] "bater, sacudir, chacoalhar, fazer ruído como a machina de costurar, o relógio, o pilão" (TASTEVIN, 1923, p. 614) / mover-se

catú: [TA e NHE] bom, bem

cê me arrhoôu: [NHE] cemiara oú: ele(a) come a sua presa, ele(a) come a presa dele(a)

cinhim: [NHE] cinhi, cini: brotar

cipriuara: [NHE] cepiriuara: aquele que vem até mim, aquele que vem junto a mim, aquele que vem ter comigo \{por extensão: o meu visitante\}; “Cepiriuára - Alguém que veio a mim, visita” (CoSTA, 1909, p. 183)

ciririca: [NHE] escorregar, deslizar

Coema-Piranga (nome de onça): [NHE] madrugada, alvorada \{literalmente: manhã vermelha\} ${ }^{26}$

cuéra: [NHE] que foi, que já era \{passado nominal\}

curuba: [TA] doença de pele, sarna, verruga, espinha; [LGA] curúba: sarna (ARRONCHES, 1935, p. 236); [NHE] curúba: sarna, tinha (TASTEVIN, 1923, p. 618); [PT/T] bicho da sarna, sarna, coceira (CA)

[25] Para os tupis da costa o cauim era uma bebida fermentada de mandioca, mas na língua geral passa a designar diferentes bebidas alcoólicas, aludindo, na maioria das vezes, à cachaça: "cãwi - Agua ardente, qualquer alcool” (TASTEVIN, 1923, p. 615); "cãohim - cachaça” (COSTA, 1909, p. 182)

[26] Segundo Couto de Magalhães (1975, p. 78), era como se nomeava o período entre 4h e $6 \mathrm{~h}$ da manhã. 
cutuca: [NHE] espetar, cutucar, fincar

eh-eh: [TA e NHE] eẽ: $\operatorname{sim}^{27}$

erê!: [NHE] certo! de acordo! está bem \{Hoje, no Rio Negro, pronuncia-se "eré!" ou "aré!".\}

he: [NHE] "He! (aspirado): diz o que está angustiado, ou triste" (FARIA, 1858, p. 22)

heeé: [NHE] heeé!! sinal de terror, pânico (SímPSon, 1955, p. 111)

iá: [NHE] "oh! é possível!" (FARIA, 1858, p. 22) / sinal de dúvida (SímPSON, 1955, p. 111); interjeição de dúvida: "covarde! fraco! apenas isso!" (DA Silva, 1945, p. 166)

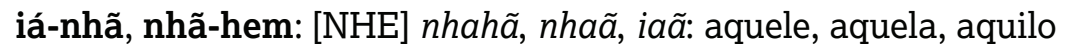
iquente: [NHE] perto

ixe, ixé: [TA e NHE] eu \{GR parece brincar com os diferentes significados atribuídos às formas similares "ixe" - "exclamação de espanto, ironia ou desprezo" (CA); "exclamação irônica" (GR) - e ixé - pronome pessoal "eu", em tupi.\}

jababora: [TA] îabab "fugir" + bor(a) "suf. que expressa o agente habitual, hábito, frequência": fujão, fujões

jaguanhenhém, jaguanhém: [TA] îagua-nhe'enga: voz de onça, fala de onça, língua de onça \{Este termo também seria usado em tupi com o significado de "rugido de onça"\}; "yagua-ñeẽ - s. falar de onça ou cão, mio, ladrido; verb. intr.: miar, ladrar, rosnar" (GR)

jaguaraím: [TA] îaguara + -ĩ: oncinha; "yaguar-aĩ - oncinha, cachorrinho" (GR) jaguarainhém, jaguaranhinhenhém : [TA] îaguarĩnhe'enga: voz de oncinha

jaguarapinima, jaguara-pinima: [TA] onça pintada

jaguaretama: [TA] îagûara + retama: terra de onças

jaguaretê: [TA e NHE] onça

jaguaretê-pinima: [TA e NHE] onça pintada

jaguaretê-pixuna: [NHE] onça preta, pantera negra

jaguariara: [TA e NHE] îaguara + îara: dono de cachorros; "yaguar-iyar - : dono, senhor de cães; caçador que caça com cães" (GR $)^{28}$

jerejereba: [TA] ficar girando, virando, revirando-se \{frequentativo de îereb: girar, virar\}

jucá: [TA e NHE] iuká: matar 
juca-jucá: [TA e NHE] iuká-iuká \{frequentativo de iuká\}: ficar matando; matar muitos, matar seguidamente

manhuaçú: provavelmente de amana + uasu : "chuva copiosa, tempestade" (SAMPAIO, 1928, p. 260) ${ }^{29}$

Mar'Iara (antropônimo): [NHE] iara: indicador de posse - o(a) do(a) / senhor(a), amo(a), dono(a) ${ }^{30}$

Maramonhangara (nome de onça): [NHE] brigador(a), lutador(a), guerreiro(a)

marupiara: [NHE] sortudo; bem sucedido na caça e na pesca \{contrário de panema\}

membeca: [TA e NHE] mole

mimbauamanhanaçara: [NHE] mimbaua "animal doméstico, criação" + manhana "espiar, vigiar, tomar conta" + -sara "sufixo que indica o agente; transmite a ideia de hábito, profissão": tomador de conta de animais de estimação, ou seja, guardador de rebanhos, vaqueiro; "Mimbauamanhanaçára - Pastôr" (CosTA, 1909, p. 197)

mixiri: [NHE] assado

mocanhemo: [NHE] muakanhemo: assustar, espantar ${ }^{31}$

mopoama: [NHE] levantar \{algo ou alguém\}

mopoca: [NHE] estourar, arrebentar \{algo ou alguém\}

Mopoca [NHE] (nome de onça): estourar, arrebentar

morubixaba: [TA] chefe, cacique, governante

Mpú (nome de onça): [NHE] enxotar, tocar, expulsar ${ }^{32}$

[29] Na edição utilizada neste trabalho consta a forma manhuaçá (RosA, 2007, p. 207). No entanto, em dois dactiloscritos do conto, feitos por GR, por nós consultados, a palavra aparece grafada como manhuaçú (IEB-USP - JGRM07,01, p. 13; JGRM07,02, p. 15). Este termo não consta nos vocabulários e gramáticas de tupi, porém nos remete ao topônimo Manhuaçu, nome de uma cidade mineira. Apesar da etimologia desse nome ser controversa, Teodoro Sampaio, em sua conhecida obra O Tupí na Geographia Nacional atribui-Ihe o sentido de "chuva copiosa", "tempestade" (amana + uasú). O engenheiro tupinólogo corrobora sua argumentação afirmando que o nome da cidade mineira, antigamente, era pronunciado como manassú (SAMPAIO, 1928, p. 260). Tal explicação etimológica, sendo ou não correta, deve corresponder ao sentido pretendido por GR em seu conto.

[30] lara é um termo que gera ambiguidades quando não inserido num contexto. Maria iara pode significar "o de Maria”, "o da Maria”, em frases como Kuá rosário Maria iara (Este rosário é o da Maria). Pode significar, porém, em outros contextos "o amo de Maria", o "senhor da Maria". Dentro do contexto explicado em nossa análise, em que relacionamos o termo à oração de Dom Frederico Costa, pensaríamos Mar'lara como contração de Maria iara, que equivaleria a "o da Maria”, "a da Maria”. Se considerarmos, entretanto, que há aí a utilização da palavra de língua portuguesa "mar", poderíamos traduzir como "senhora do mar".

[31] Pelo contexto, muakanhemu faz mais sentido do que mukanhemo (fazer sumir, fazer desaparecer, fazer perder-se, dispersar, desolar). Essas formas verbais, às vezes, confundem-se na literatura. Numa das narrativas publicadas em Lendas em Nheengatu e em Português, por exemplo, vemos o verbo mukanhymo com o sentido de "espantar" (AMORIM, 1987, p. 219).

[32] GR, provavelmente, alude ao sentido particípio do verbo, que é a forma como o dicionário de Stradelli (2014) traduz seus verbetes. Assim, é bem provável que a intenção do autor tenha sido a de nomear esta onça como "enxotada", "expulsa". 
mucunando: [NHE] mukuna: engolir [GR utiliza a morfologia de gerúndio característica da língua portuguesa sobre a base verbal do NHE\}

muçuruca: [NHE] rasgar ${ }^{33}$

mundéu: [NHE] enfiar, meter / vestir

mundéu-mundéu: [NHE] ficar enfiando, ir enfiando / ficar vestindo \{frequentativo de mundéu\}

munguitar: [NHE] munguitá, munguetá, monguetá: aconselhar, recomendar / conquistar, seduzir, persuadir / combinar, conchavar ${ }^{34}$ munhãmunhã: [NHE] munhamunhã: zombar, escarnecer, caçoar

muquiada: [NHE] mukiá: sujar [GR utiliza a morfologia de particípio característica da língua portuguesa sobre a base verbal do NHE\}

muquirica: [NHE] fazer cócegas

mururú: [NHE] molhar; molhado

n't, n't; ti: [NHE] inti, nti, ti: não

Nhã-ã (nome de onça): [NHE] correr ${ }^{35,36}$

nhem?, nhenhém?: [NHE] nheem, nheẽ: falar, dizer ${ }^{37}$

nheengava: [TA] nhe'eng: falar / [TA] nhe'engar: cantar \{GR utiliza a morfologia de pretérito imperfeito característica da língua portuguesa sobre a base verbal do TA\}

pa!: [NHE] "vá ele!" (SímPSON, 1955, p. 111); interjeição de horror: "vá ele!, deus me livre!, livra!” (DA SiLvA, 1945, p. 166)

[33] Na edição utilizada neste trabalho consta a forma muçuruça (RosA, 2007, p. 206), que não possui significado em tupi. No entanto, verificamos que em dois dactiloscritos do conto a forma utilizada por GR foi muçuruca (IEB-USP - JGRM07,01, p. 12; JGRM07,02, p. 15), que é corretamente grafada em outras edições impressas da obra.

[34] GR, provavelmente, pretendeu a acepção de "seduzir", que é um dos sentidos que constam no vocabulário de Frederico Costa: "munguitá - seduzir, conchavar" (COSTA, 1909, p. 199).

[35] Aqui, novamente, GR deve ter aludido ao sentido particípio do verbo (corrida), ou seja, Nhã-ã é a onça que foi tocada, expulsa. A fonte desse nome foi, provavelmente, o dicionário de Stradelli (2014, p. 441), no qual vemos o verbete "nhaã, nhaan: corrido". O verbo "correr" mais frequentemente aparece como nhana ou iana na língua geral. A última forma corresponde à pronúncia atual do Rio Negro. Nhã-ã poderia também aludir ao demonstrativo nhaã (aquele, aquela, aquilo), o contexto, porém, invalida esta acepção.

[36] Em carta a um tradutor italiano, GR discorre sobre o sentido desta palavra, referindo-se, porém, à sua utilização em outra de suas obras, o conto Recado do Morro: "nhã-ã = anhangá (o diabo dos índios tupis e guaranis, dado em forma de propósito deturpada, reduzida a 'fórmula')" (RosA apud MARTins, 2001, p. 350). Na mesma carta ele refere-se a outros termos que entrariam em ressonância com nhã-ã, possibilitando uma multiplicidade de conotações.

[37] Ao mesmo tempo em que estas formas são entendidas como "o quê?" e "quê?" em português, em tupi antigo e em nheengatu podem ser interpretadas, respectivamente, como os verbos nhe'eng (falar) e nheẽ (falar, dizer). 
panema: [TA e NHE] azarado, imprestável ${ }^{38}$

peba: [TA] chato(a), achatado(a)

pereba: [TA] ferida

peteca: [NHE] dar tapa, estapear, esbofetear, dar pancadas, bater

Petecaçara (nome de onça): [NHE] o que dá tapas, o que dá bofetadas

Péua (etnônimo): [NHE] referência ao povo tacunapeua

pinima: [TA, NHE e PT/T] pintado / [TA e NHE] desenhado

pipica: [NHE] gotejar /alagar

pipura: [NHE] rastro, pegada

piriri: [GUA] "ruído breve, seco, repetido, agudo, como o produzido pelo sal grosso atirado ao fogo ou galhos e folhas secas ao quebrarem-se sob os pés" (SANABRIA, 2010, s/p.) 39; "ruído produzido ao se pisar papéis" (MELIÀ, 2003, p. 107) (0 $^{40}$

piririca: [NHE] "fritar, crepitar, estalar, estremecer, sussurrar" (TASTEVIN, 1923, p. 653) / engelhar (CosTA, 1909, p. 203)

pitar: [PT] \{provavelmente do GUA pita\} fumar ${ }^{41}$

pitume: [NHE] pitima: fumo, tabaco; $[\mathrm{PT} / \mathrm{T}]$ petume, petum: tabaco ou fumo (CA)

pixuna: [NHE] preto(a)

popóre: [NHE] po-pore, pu-pure \{reduplicação do verbo pore ou pure: pular\}: ficar pulando, trotar

pô-pu, pô-pu: [NHE] po e pu são palavras que designam a "mão", dando a esta expressão o sentido de "mão a mão", "uma mão por vez", ou melhor, "uma pata por vez", no caso da onça \{para animais, po ou pu são utilizados em referência às patas dianteiras\}.

poranga: [NHE] bonito, bom, bem

porã-poranga: [NHE] muito bonito, muito bom, muito bem \{reduplicação do adjetivo poranga\}

Puxuêra (nome de onça): [NHE] feio, ruim, mal

querembáua: [NHE] valente, corajoso, forte

quicé: [NHE] faca

[38] É comum dizerem assim daquele que fracassa na caça ou na pesca, bem como de arma que traz azar ao caçador.

[39] Tradução nossa de: "Ruido breve, seco, repetido, de tonalidad alta, como el producido por la sal gruesa tirada al fuego o las ramitas y hojas secas al quebrarse bajo los pies." (SANABRIA, 2010, s/p.)

[40] Tradução nossa de: "ruído del pisar papeles" (MELIÀ, 2003, p. 107)

[41] Alguns dicionários de guarani consideram que este verbo entrou no seu vernáculo como empréstimo oriundo da língua Quéchua. 
remuaci... reiucáanacê: [NHE] tenha piedade!... você já me matou...

ropitando: [NHE] ropitá: atrás, detrás (SímPSON, 1955, p. 110 ${ }^{42}\{\mathrm{GR}$, neste caso, estaria utilizando a morfologia de gerúndio característica da língua portuguesa sobre a base lexical do NHE.\} / [TA] (e)ropyta: fazer ficar consigo, fazer permanecer consigo \{possibilidade mais remota\} roró (d'água): [provavelmente do TA] tororoma: jorro, jato, borbotão sacapira: [NHE] ponta de algo, extremidade de algo \{literalmente: ponta dela, sua ponta\}

sacaquera: [NHE] atrás dele(a); em seu encalço

sacêmo: [NHE] gritar, gemer ${ }^{43}$

sacê-sacêmo: [NHE] ficar gritando, ficar gemendo, ficar rugindo \{frequentativo do verbo sacêmo: gritar, gemer\}

sapecado: $[\mathrm{PT} / \mathrm{T}]$ \{de (s)apek: tostar, sapecar\} "diz-se do que está chamuscado, ligeiramente queimado ou ressecado pelo fogo" (CA). sapijara: [talvez do NHE] sapé iara: senhor do caminho dele (a), guia dele (a) \{ver nota em tapijara\}

sejuçú: [NHE] constelação das plêiades ${ }^{44}$ será: [NHE] expressão utilizada na formação de questões em nheengatu, sobretudo para perguntas fechadas, ou seja, aquelas que pressupõem como resposta os advérbios "sim" ou "não".

sossoca: [NHE] socos repetidos, sequência de socos, de soquinhos soroca: $[\mathrm{PT} / \mathrm{T}]$ \{de yby-soroka: terra rasgada\}fenda na terra, toca de onça suaçurana: [NHE] o que parece veado mas não é, falso veado $\{0$ termo faz referência à suçuarana, também conhecida por onça parda, onça vermelha ou puma. $\}^{45}$

[42] Símpson, na verdade, não é muito preciso, pois ropitá, ou rupitá, seria mais bem traduzido por "base", "origem", "tronco", assumindo por extensão outros sentidos, como o de "parede", quando nos referimos a uma construção. Em alguns casos, como, por exemplo, no de uma canoa (igara), podemos chamar de igara rupitá a sua popa, que é de fato a sua parte traseira. Seja como for, o sentido referido por Símpson pode ter influenciado na cunhagem do verbo utilizado por GR.

[43] Este verbo é o que se utiliza em nheengatu com relação ao som emitido por muitos animais, tomando o significado de "rugir" quando atribuído a uma onça; "latir", quando atribuído a um cachorro etc.

[44] No tupi antigo as plêiades eram chamadas de seîxu (NAVARRO, 2013). No nheengatu o nome assumiu formas que diferem um pouco segundo suas variações dialetais, às quais se somam, na literatura, as diferenças oriundas das grafias distintas utilizadas pelos que registraram o termo. Encontram-se nos registros, entre outras, as formas: sejuçu, seyuč, cyiucé, ceiuci e ceucy. Atualmente, no Alto Rio Negro, diz-se siiuci ou seiuci.

[45] No tupi antigo, entre outras formas registradas, temos suasuarana (provavelmente, de suasu "veado" + a(ba) "pelo" + -ran(a) "semelhante", "o que parece mas não é”). É interessante notar que a pronúncia mais comum da palavra em seu empréstimo para a língua portuguesa - "suçuarana" -, não pode ser decomposta em constituintes que possuem significado em tupi (antigo ou nheengatu), já a forma utilizada por GR, pode ser traduzida por "falso veado", "o que parece veado, mas não é". 
Sucuriú (topônimo): provavelmennte de sukuri + 'y: rio das sucuris suú: [NHE] animal \{sobretudo os quadrúpedes\}; caça / morder

Suú-suú (nome de onça): [NHE] mastigar suú-suú: [NHE] mastigar

Tacunapéua (etnônimo): [talvez do NHE] takunha + peua: pênis chato, achatado

tagoaíba: [LGA] tagoáyba: fantasma (DIAS, 1858, p. 163); tagoaib: fantasma (ARRONCHES, 1935, p. 135)

tá-há: [NHE] partícula de interrogação, sobretudo para perguntas abertas, ou seja, que admitem muitas respostas

tapijara: [TA] tapijara: "morador antigo ou q. está de assento" (VOCABULARIO, 1938, p. 300); [LGA] tapijára: morador (ARRONCHES, 1935, p. 175) / [LGA] tapyjara: "quando alguem tem de costume fazer algumas couzas boas ou más, se diz tapyjara" (FRANÇA, 1859, p. 35); [NHE] tapé-iara: useiro e vezeiro (STRADELLI, 2014, p. 492) \{ou seja, "que tem o costume de agir de certa maneira, fazer determinada coisa frequentemente" (CA)\} / [LGA] tapejára: "pratico do caminho" (DiAS, 1858, p. 165) ${ }^{46}$

tapuitama: [LGA] tapuytáma: sertão (O DicCIONARIO, 1896, p. 151); tapuya táma: sertão (DiAS, 1858, p. 165) \{de tapuî(a) + retama: terra de tapuias\}

tataca: [NHE] casta de rã arbórea (STRADELLI, 2014, p. 495)

[46] Stradelli indica em seu verbete para "useiro e vezeiro" (2014, p. 303), na parte português-nheengatu de sua obra, que a etimologia de tapé-iara seria "senhor do caminho". A forma correta para "senhor do caminho", no entanto, é pé-iara, cujas formas relacionadas são sapé-iara e rapé-iara. O termo pé (caminho) é pluriforme, ou seja, dependendo da presença ou não de relação genitiva com outro substantivo ou com um pronome que o anteceda, pode assumir as formas pé, sapé ou rapé. Os pluriformes regulares da língua, por outro lado, mantêm uma mesma base, sobre a qual se alteram unicamente os prefixos ( $t-, \mathrm{s}$ - e $r$-). Assim, temos, por exemplo, os trios: tetama, setama, retama (terra, região), timbiú, simbiú, rimbiú (comida, alimento) etc. A analogia com o padrão regular dos substantivos pluriformes parece ter influenciado a interpretação do vocábulo tapé-iara, no qual se passou a vislumbrar a forma tapé, valendo por pé (caminho). Isso já é percebido no verbete de Dias (pratico do caminho). Parece, portanto, ter havido ao longo do tempo uma associação entre o termo tapijara e a expressão pé-iara (senhor do caminho, guia), embora originalmente não houvesse relação direta entre as duas formas. É possível que os vocábulos tapijara e sapijara utilizados por GR carreguem a mesma carga semântica, diferindo apenas por prefixos de relação ( $t$-, sem relação genitiva, e s-, relacionado ao pronome de terceira pessoa do singular). Se foram utilizados com a pretensão de valerem pelos sentidos mais antigos que se atribui à palavra tapijara, ou seja, como "morador", poderíamos traduzi-los, respectivamente, por "morador" e "morador dela" ("morador da onça”, "o que habita a onça”, pelo contexto). Deve-se dizer, entretanto, que não encontramos registros de que a palavra fosse pluriforme, ou seja, de que assumisse a forma sapijara com esta acepção, o que pode, contudo, ficar a cargo do trabalho de criação linguística de GR. Se o escritor utilizou as palavras com o sentido de "senhor do caminho", tapijara e sapijara poderiam ser traduzidos, respectivamente, por "o senhor do caminho" e "o senhor do caminho dela (da onça)", donde provêm os sentidos de "guia" e "guia dela (da onça)". É possível, também, que GR tenha pretendido uma superposição de todos os sentidos aqui referidos. 
Tatacica (nome de onça): [TA] tatá + syka: chegada do fogo / [NHE] tatá + sica: resina de fogo, ou seja, resina que dá fogo, resina inflamável \{possível menção ao breu, "matéria escura, sólida e inflamável, que se obtém pela destilação do alcatrão da hulha ou de resinas de plantas (...)" (CA)\} ${ }^{47}$ / [NHE] tatá-cica: tição (STRADELLI, 2014, p. 297) \{de tatá + acyka: pedaço de fogo\}

tatu-hu: [TA] comer tatu

teité, teitê: [NHE] coitado

Tibitaba (nome de onça): [TA] tybytaba: sobrancelhas (NAVARRO, 2013, p. 485); [LGA] tybytába: sobrancelhas (DIAS, 1858, p. 177)

tiquira: [NHE] gota / [PT/T] aguardente obtida por destilação

tubixaba, tuxa: [TA e NHE] chefe, principal; grande

tutira: [NHE] tio ${ }^{48}$

Uatauêra (nome de onça): [NHE] o que anda, o que caminha, o caminhante uauaca: [NHE] "à roda, ao redor" (SÍMPSON, 1955, p. 110); uauoca: rodar (STRADELLI, 2014 p. 513); "wawaca: redomoinhar, torvelinhar, andar à roda" (TASTEVIN, 1923, p. 675)

uêuê: [NHE] voar

Uinhúa (nome de onça): [talvez do NHE] uíua: flecha ${ }^{49}$

Uitauêra (nome de onça): [NHE] o nadador, o que nada

urucuera: $[\mathrm{PT} / \mathrm{T}]$ variedade de curuja

Urucúia (topônimo): \{de uruku + 'yba\} urucuzeiro, pé de urucum

Ururau (topônimo): [TA] variedade de jacaré (NAVARRo, 2013, p. 503)

[47] A palavra do tupi antigo ysyka (goma, resina) resultou no termo nheengatu que, entre outras formas, encontramos na literatura como isica ou sica. Tastevin escreve "sica ou isica - gomma, resina" (TASTEVIN, 1923, p. 665). A aférese da vogal inicial pode ser vista já na língua geral do século 18: "resina - cica" (ARRONCHES, 1935, p. 229). O breu, no nheengatu, costuma ser referido, dependendo de seu tipo, por isicantá (resina dura) ou iraiti, do tupi antigo iraîty (cera). No entanto, a relação genitiva de sica (resina) com tatá (fogo) pode aludir à capacidade da resina de gerar ou manter o fogo, o que é típico do breu. Algo análogo pode ser visto no verbete de Stradelli para tatá itá: "pedra de fogo, que dá fogo, sílex" (2014, p. 495). A alusão ao breu, matéria tipicamente escura, condiz com a descrição que GR faz da onça: "Mais adiante, tem a Tatacica, preta, preta, jaguaretê-pixuna..." (RosA, 2007, p. 211)

[48] No tupi antigo tutyra designava apenas os tios maternos. Em nheengatu, no entanto, seu derivado tutira passa a designar indistintamente os tios maternos e paternos.

[49] A descrição que GR (2007, p. 217) faz da movimentação desta onça pode explicar sua nomeação: "(...) tá indo escorregada, no capim grosso. Ela vai, anda deitada, de escarrapacho, com as orelhas pra diante (...). Fica peba no chão". Como a onça fica achatada (peba) no chão com as orelhas apontadas pra frente, sua silhueta lembra a uma seta que se encaminha em direção ao alvo. 
Além das palavras apresentadas acima, segue abaixo uma lista de palavras oriundas do tupi que aparecem no conto, mas que, por serem utilizadas corriqueiramente no léxico da língua portuguesa, muitas pessoas não se atentam à sua origem:

araçá; arara; araticum; buriti; caititu; capim; capivara; catinga; cipó; coité; embira; gravatá; guará; ipê; jabuti; jacu; jaguatirica; jirau; mandioca; mangabeira; moqueado; paca; paçoca; pajé; peroba; sambaíba; saracura; sariema; socó; sucuri; sucuriju; tamanduá; tatu; tipoia; tucano; urubu 


\section{ANEXO 1 - TRADUÇÃO DA ORAÇÃO CATÚ RETÉ ROSÁRIO, DO BISPO D. FREDERICO COSTA}

Catú reté Rosário

I

Catú reté Rosario ${ }^{50}$

Virgem Mar'Iára;

Iuáca rapé

Iané raçuçara!

II

Padre Nosso - imbueçaua

Christu Iané Iára,

Rupi çaiçuçaua ${ }^{51}$, Iané umbué.

III

Rosário Manha, Iuáca Iára,

Xa-serviri putari

Catuçaua neiára.

IV

Xa-putari, Ce Iára,

Ce manuçaua ramé,

Ne Rosario curi

Ce picirúçaua reté.

$\mathrm{V}$

I-Paia Gloria,

Tahira iuïri

Espirito Santo iüriri ${ }^{52}$

Upain ara. Iaué.
Bendito Rosário

I

Bendito Rosário,

O da Virgem Maria;

Do Caminho do céu

O nosso guia!

\section{II}

A oração do Padre Nosso

Cristo Nosso Senhor,

Por amor,

Nos ensinou.

III

Mãe do Rosário,

Senhora do Céu,

Eu quero servir

À tua bondade.

IV

Eu quero, Minha Senhora, Que no momento de minha morte

Seja o teu Rosário

Minha verdadeira salvação.

$\mathrm{V}$

A Glória do Pai,

E do filho

E do Espírito Santo

Todos os dias. Assim.

[50] Literalmente: "Rosário muito bom" ou "Rosário muito bondoso".

[51] Neste verso, para conseguir a rima pretendida, o bispo abriu mão da gramática. A única forma coerente e correta seria çaiçuçaua rupi (por amor). 
MARCEL TWARDOWSKY ÁVILA \& RODRIGO GODINHO TREVISAN - Mestrandos do programa de Estudos da Tradução vinculado ao Departamento de Letras Modernas da Universidade de São Paulo. E-mails: marcel.avila@usp.br e rodrigotrevisan@usp.br

Gostaríamos de agradecer à professora Lúcia Sá por nos ter apresentado o conto Meu tio o Iauaretê na disciplina Literaturas da Floresta, ministrada no segundo semestre de 2014 na Universidade de São Paulo, bem como agradecê-la pela indicação à revista Magma para que o presente estudo fosse publicado. Também gostaríamos de agradecer aos funcionários do Instituto de Estudos Brasileiros da USP pela prestatividade e gentileza com que sempre nos atenderam. 


\section{REFERÊNCIAS}

AMORIM, Antônio Brandão de. Lendas em nheengatu e em português. Manaus: Fundo Editorial - ACA, 1987.

ARRONCHES, João de. O caderno da lingua;ou. Vocabulario portuguez-tupi de frei João de Arronches, 1739; notas e commentarios á margem de um manuscripto do sec. XVIII. [Organizado por Plinio Ayrosa] São Paulo: Imprensa official do estado, 1935.

BENDITO Rosário. [S.I.]: Scribd., [201-]. Disponível em: <http://pt.scribd.com/ doc/91640937/Bendito-Rosario\#scribd>. Acesso em: 5 de maio de 2015.

CAMPOS, Haroldo de. "A Linguagem do lauaretê". In: Metalinguagem \& outras metas. São Paulo: Perspectiva, 1992, pp. 57-63.

CHAMBOULEYRON, Rafael. "O Sertão dos Taconhapé. Cravo, Índios e Guerras no Xingu Seiscentista”. In.: Histórias do Xingu - Fronteiras, Espaços e Territorialidades (Séculos XVII-XXI). Org.: Célio Martins de Souza e Alírio Cardozo. Belém. Editora Universitária UFPA, 2008, pp. 51-74.

CHAMBOULEYRON, Rafael; MELO, Vanice Siqueira de. Aleivosias e extorsões do gentio na Amazônia colonial. Texto integrante dos Anais do XIX Encontro Regional de História: Poder, Violência e Exclusão. ANPUH/SP-USP. São Paulo, 08 a 12 de setembro de 2008, pp. 1-12.

COSTA, Frederico. "Elementos necessários para aprender o nheengatu”. In: Carta pastoral de D. Frederico Costa, bispo do Amazonas a seus amados diocesanos. Ceará: Typ. Minerva, 1909, pp. 157-248.

DA SILVA, Protásio I. R. Tupi ou Nheengatú: garamática umbueçáua mucameençáuêra. Manaus: Seção das Artes Gráficas da Escola Técnica de Manaus, 1945.

DIAS, Antonio Gonçalves. Diccionario da língua tupy chamada língua geral dos indígenas do Brazil. Lipsia: F. A. Brockhaus, livreiro de s.m. o imperador do Brazil, 1858. (Bibliotheca Linguistica, v. 1). Disponível em: <http://books. google.com.br/books?id=6RcJAAAAQAAJ\&printsec=frontcover\&redir_e $\mathrm{sc}=\mathrm{y} \# \mathbf{v}=$ onepage $\& \mathbf{q} \& \mathrm{f}=\mathrm{false}>$. Acesso em: 20 de abril de 2015. 
DICIONÁRIO AULETE DIGITAL. [S.I.]: c[201-]. Disponível em: <http://www.aulete.com.br/>. Acesso em: 22 de abril de 2015.

DICIONÁRIO eletrônico Houaiss da língua portuguesa. Rio de Janeiro: Objetiva, 2001. 1 CD-ROM.

DICIONÁRIO PRIBERAM DA LÍNGUA PORTUGUESA. [S.I.]: c[201-]. Disponível em: <http://www.priberam.pt/dlpo/arar>. Acesso em: 17 de abril de 2015.

FARIA, Francisco Raimundo Correia de. Compendio da lingua brazilica para uzo dos que a ella se quizerem dedicar. Pará: Typ. de Santos \& Filhos, 1858.

FERREIRA, Aurélio Buarque de Holanda. Novo dicionário Aurélio da língua portuguesa, 3. ed. rev. e atual. Curitiba: Positivo, 2014.

FRANÇA, Ernesto Ferreira. Chrestomathia da língua brasilica. Leipzig: F. A. Brockhaus, livreiro de s. m. o imperador do Brazil, 1859.

FREIRE, José Ribamar Bessa. Rio Babel: a história das línguas na Amazônia. 2. ed. Rio de Janeiro: EdUERJ, 2011.

HOLANDA, Sérgio Buarque de. "A língua-geral em São Paulo". In.: Raízes do Brasil. 26. ed. São Paulo: Companhia das Letras, 1995, pp. 122-133.

MAGALHÃES, José Vieira Couto de. O Selvagem. São Paulo: EDUSP; Belo Horizonte: Itatiaia, 1975.

MARTINS, Nilce Sant’Anna. O léxico de Guimarães Rosa. São Paulo: EDUSP, 2001.

MELIÀ, Bartolomeu. Dicionário básico: guarani-castellano/ castellano-guaraní. Paraguay. Centro de Estudos Paraguaios “Antonio Guasch” - CEPAG, 2002.

NAVARRO, Eduardo de Almeida. Dicionário de tupi antigo: a língua indígena clássica do Brasil. São Paulo: Global, 2013.

O DICCIONARIO anonymo da lingua geral do Brasil, publicado de novo com seu reverso por Julio Platzmann. Edição facsimilar. Leipzig: B. G. Teubner. 1896.

RODRIGUES, João Barbosa. Poranduba amazonense. Rio de Janeiro: Tipografia de G. Leuzinger \& Filhos, 1890. 
ROSA, João Guimarães. "Meu tio o lauaretê". In: Estas estórias. 5. ed. Rio de Janeiro: Nova Fronteira, 2007, pp. 191-235.

SAINT-HILAIRE, Auguste de. Viagem às nascentes do rio S. Francisco e pela provincia de Goyaz. São Paulo, SP: Ed. Nacional, 1937. 2v.

SAMPAIO, Teodoro. O tupí na geographia nacional. 3. ed. corr. e augm. Bahia: Escola de Aprendizes Artifices, 1928.

SANABRIA, Lino Trinidad. Mi pequeño avañe'ẽ de mochila. 1a ed. - Buenos Aires: Ruy Díaz, 2010.

SÍMPSON, Pedro Luís. Gramática da língua brasileira: brasílica, tupi ou nheengatu. 5. ed. Rio de Janeiro: Impressão do Jornal do Brasil, 1955.

STRADELLI, Ermano. Vocabulário Português-Nheengatu, Nheengatu-Português. Cotia, SP: Ateliê Editorial, 2014.

TASTEVIN, Constantino. “Vocabulario Tupy - Portuguez”. In: Grammatica da Lingua Tupy. São Paulo: Officinas do Diario Official, 1923, pp. 599-686. [Separata do Tomo XIII da Revista do Museu Paulista]

VOCABULARIO na lingua brasilica manuscrito português-tupí do século XVII, coordenado e prefaciado, Plinio Ayrosa, São Paulo: Departamento de Cultura, 1938. 


\section{REFERÊNCIAS CONSULTADAS}

AZEVEDO, Orlando; MARGOTTI, Felício. "O sufixo -rana no português falado pelo caboclo amazonense”. In: Revista Alfa, 56 (2). São Paulo, 2012, pp. 611-621.

LOBO, Tânia C. Freire et al. "Indícios de língua geral no sul da Bahia na segunda metade do século XVIII”. In: LOBO, Tânia et al. (Org.). Para a história do português brasileiro. vi: novos dados, novas análises. Salvador: EDUFBA, pp. 609-630.

NAVARRO, Eduardo de Almeida. Curso de língua geral (nheengatu ou tupi moderno): a língua das origens da civilização amazônica. São Paulo: copyright Eduardo de Almeida Navarro, 2011.

Método moderno de tupi antigo: a língua do Brasil dos primeiros séculos. 3. ed. São Paulo: Global, 2005. 